Monterrubio Ibáñez, Lourdes (2019). "Dispositivos de enunciación del film-ensayo español contemporáneo: Evolución de la subjetividad ensayística y su pensamiento en acto". Studies in Spanish \& Latin American Cinemas, 16:3, pp. 335-361, https://doi.org/10.1386/slac_00003_1

Accepted Manuscript

\title{
Dispositivos de enunciación del film-ensayo español contemporáneo. Evolución de la subjetividad ensayística y su pensamiento en acto
}

\author{
Lourdes Monterrubio \\ Complutense University of Madrid
}

\section{Resumen}

El presente artículo analiza los dispositivos de enunciación del film-ensayo español contemporáneo. Para ello, realizamos un itinerario por sus obras más significativas, a partir de la evolución de los dispositivos de enunciación textuales y sus diferentes funciones: voz off, voz in, subtítulos, intertítulos, y la desaparición del texto. Este recorrido nos permite analizar la relación entre estos dispositivos y: las formas intermediales (la carta, el diario, el auotorretrato, etc.); los materiales audiovisuales (imágenes propias, found footage, animación, fotografía, pintura, etc.); y los elementos retóricos utilizados (yuxtaposición, pantalla en negro, fundido, sobreimpresión, ralentización, pantalla dividida, etc.). Se evidencia entonces cómo el film-ensayo español contemporáneo genera una progresiva deconstrucción de la subjetividad ensayística mediante procedimientos asociados a los dispositivos de enunciación analizados - ficcionalización, sustracción, desautomatización, objetivación, desintensificación, descentramiento y borrado - que oscilan entre los polos de la reflexión racional y la emocional.

Palabras clave: film-ensayo, cine español contemporáneo, dispositivos de enunciación, intermedialidad, pensamiento cinematográfico, subjetividad, análisis fílmico 


\begin{abstract}
This article analyses the enunciative devices of the contemporary essay-film in Spain. It studies the most significant works, analysing their textual enunciative devices and their different functions: voice-over, voice in, subtitles, intertitles, and the disappearance of the text. It also analyses the relationship between these devices and intermedial forms (the diary, the letter, the self-portrait), audio-visual materials (author's own filming, found footage, animation, photography, painting, etc.) and the rhetorical elements used (juxtaposition, black image, fade, overprint, deceleration, split screen, etc.). It concludes that the contemporary Spanish essay film generates a progressive deconstruction of essayistic subjectivity through procedures associated with the enunciative devices analysed - fictionalisation, subtraction, desautomatization, objectivation, desintensification, decentering and erasure - which oscillate between the poles of rational and emotional reflection.
\end{abstract}

Keywords: essay film, contemporary Spanish cinema, enunciative devices, intermediality, cinematic thinking, subjectivity, film analysis

\title{
1. Introducción
}

Este análisis de los dispositivos de enunciación del film-ensayo español contemporáneo tiene como premisa la definición más exigente de esta forma fílmica que materializaría el proceso de pensamiento y la autorreflexión de una subjetividad o subjetividades. Por tanto, la 'presencia del yo del autor, del ensayista' y 'la revelación de un pensamiento en acto' (Moure 2004: 37) son condiciones necesarias que determinan la enunciación de la obra: 'el autor está siempre ligado a este proceso [de pensamiento] y no es posible huir de esa presencia, puesto que la obra en sí no es otra cosa que la constatación de esta' (Català 2014: 143).

Es preciso entonces diferenciar entre la forma fílmica del film-ensayo así definida y los dispositivos de enunciación de la subjetividad(es) del autor(es) que la generan, ya que ambas instancias son confundidas a menudo, situando el film-ensayo junto a lo que denominamos formas intermediales de enunciación, como el diario, la carta, el autorretrato, etc. A partir de esta clara diferenciación de conceptos, realizamos un primer estudio de los dispositivos enunciativos instrumentalizados por el film-ensayo español contemporáneo y analizamos su evolución en relación a sus tres características definitorias: subjetividad, proceso de pensamiento y autorreflexividad. Retomando los 
postulados de Gilles Deleuze (1985) sobre el intersticio, y su condición de 'germen del pensamiento cinematográfico’ (Monterrubio 2018: 94), asumimos también la propuesta de Laura Rascaroli de la materialización de un 'pensamiento intersticial': 'the essay film, as thinking cinema, thinks interstitially - and that, to understand how the essay film works, we must look at how it forges gaps, how it creates disjunction' (2017: 190, 11). Este 'pensamiento paratáxico' (Català 2014: 206) e intersticial responde también al concepto de frase-imagen definido por Jacques Rancière en relación a su esencia audiovisual:

La frase no es lo decible, la imagen no es lo visible. Frase-imagen es para mí la unión de dos funciones que deben ser definidas estéticamente, es decir, a partir del modo en que deshacen el vínculo representativo del texto a la imagen. (2011: 64)

La frase-imagen transitará entre los polos dialéctico y simbólico: 'entre el choque que opera un desdoblamiento de los sistemas de medida y la analogía que da forma a la gran comunidad, entre la imagen que separa y la frase que tiende hacia el fraseo continuo' (Rancière 2011: 74), y ambos procedimientos pueden entremezclarse hasta alcanzar 'el límite de lo indiscernible' (2011: 76).

Si observamos el nacimiento y consolidación del film-ensayo en Francia, comprobamos que muchas de las obras referentes de esta práctica ensayística se generan a través de una clara codificación del dispositivo de enunciación, mediante formas intermediales literarias, pictóricas, fotográficas, etc. La carta: Lettre de Sibérie/Letter from Siberia (Marker, 1957), Letter to Jane (Godard, 1972), News from Home (Akerman, 1977), Lettre à Freddy Buache/A Letter to Freddy Buache (Godard, 1981), Sans soleil/Sunless (Marker, 1983). El diario: Lettres d'amour en Somalie/From Somlia with Love (Mitterrand, 1982), Level 5 (Marker, 1997). El autorretrato: Jane B. par Agnès V.JJane B. for Agnès $V$. (Varda, 1988), JLG/JLG Autoportrait de décembre/JLG/JLG Self-Portrait in December (Godard, 1994). Además, estos dispositivos de enunciación se materializan mediante primero la presencia de la voz off - siguiendo la nomenclatura y definición de Michel Chion (1982) - del ensayista (o de su intérprete, como en el caso de Chris Marker), para evolucionar más tarde a su presencia en imagen y, por tanto, a su voz in.

El advenimiento de la tecnología digital da paso a un 'ensayo electrónico' (Renov 2004: 182-90) que implica un aumento exponencial de las herramientas y elementos a 
disposición del film-ensayo para generar el pensamiento fílmico, transformando también sus dispositivos de enunciación: la mayor facilidad para trabajar con found footage, las interminables posibilidades de manipulación de la imagen, las diferentes opciones de inscripción del texto sobre la pantalla y, por supuesto, la inscripción del yo del ensayista:

the video apparatus supplies a dual capability well suited to the essayistic project: it is both screen and mirror, providing the technological grounds for the surveillance of the palpable world, as well as a reflective surface on which to register the self. (Renov 2004: 186)

Todas las obras objeto de este análisis pertenecen ya a este territorio digital. El itinerario aquí trazado presenta una reflexión sobre la evolución de los dispositivos de enunciación utilizados desde la hipótesis de una progresiva deconstrucción de la subjetividad ensayística y un debilitamiento de la codificación de los mismos en pos de la multiplicación de los elementos enunciativos.

\section{Voz off y formas intermediales: Reafirmación de la subjetividad}

Declaraba Víctor Erice tras el estreno de El sur (1984): 'A menudo he tenido la tentación de derivar hacia una estructuración cinematográfica fragmentaria, el diario íntimo, el ensayo, la reflexión, quizá con un toque de ficción’ (Molina Foix 1984: 50). Esta tentación se convierte en tentativa en La Morte Rouge (soliloqio) (2006) (Monterrubio 2019), generando las dos polaridades teorizadas por Alain Ménil (2004: 98-99), tentativa-tentación y objetividad-subjetividad:

No hay ensayo que no sea, de alguna manera, la experiencia de su propia aventura, que no sea al mismo tiempo que una búsqueda, una investigación o una indagación $a$ propósito de o con motivo de, motivo de una invención, invención de su propio método y de su propio proceso. (Ménil 2004: 101, en cursiva en el original)

Erice continúa con la caracterización del film-ensayo de la modernidad, en la que la voz off del autor-ensayista se enuncia desde un dispositivo claramente codificado, presentado desde el título: el soliloquio, así definido por la RAE: 'reflexión interior o en voz alta y a solas'. Este dispositivo textual se convierte entonces en 'herramienta de 
indagación en la propia memoria cinematográfica del director' (Balló 2012: 14). Pero no sólo de la cinematográfica, sino también de la infantil y la histórica, permitiendo al cineasta 'fundir, en único gesto, la memoria más íntima y personal con la densidad y el peso de la Historia' (Zunzunegui 2014: 57). El soliloquio es el dispositivo perfecto para crear un 'laboratorio de operaciones de la memoria' (Berthet 2011: 86), entendiendo esta última como 'una práctica y un proceso semiótico-discursivo', 'un proceso cognitivo dinámico que involucra la construcción simbólica de sentido, la semiosis' (Ricaurte 2014: 48, 53). Es entonces la articulación de la memoria - la creativa, la emocional, la histórica y la colectiva - la que posibilita el pensamiento fílmico: 'renunciar al documento para acceder a la experiencia y a la verdad, a la mirada estética sobre la propia vida' (González 2006: 200).

La memoria íntima del autor viaja entonces a su niñez para reflexionar en torno a su primera experiencia cinematográfica, la proyección del film La garra escarlata/The Scarlet Claw (Neill, 1944) en el cine Kursaal de San Sebastián el 24 de enero de 1946, a la edad de cinco años. La reflexión se construye mediante la alternancia de diferentes materiales visuales: las imágenes presentes en vídeo, color y $\mathrm{B} / \mathrm{N}$; las imágenes de archivo de la época, fotográficas y fílmicas; las fotografías personales del cineasta; la recreación ficcional de la experiencia infantil en $\mathrm{B} / \mathrm{N}$; las imágenes del film La garra escarlata, fijas y en movimiento.

La voz off del cineasta transita por ellos generando su transformación. El pensamiento cinematográfico se produce al situar la autobiografía íntima bajo el escrutinio analítico de la tercera persona. El inicial diálogo, las diferentes resonancias que surgen entre los diferentes materiales, se convierte durante la reflexión en una fusión que las hace indiscernibles en la percepción infantil. Esta fusión halla en la imagen de la ruleta de casino girando (única imagen ficcional que Erice incluye en la exposición del pasado del Kursaal) su metáfora perfecta, materializando una fraseimagen simbolista, tal y como la define Rancière. Su movimiento giratorio hace que su imagen se disuelva, como se disuelven los límites entre ficción y realidad en la mente infantil.

El fundido encadenado, que se ralentiza en momentos clave hasta la sobreimpresión, es el elemento retórico principal de este pensamiento en acto. La imagen de archivo del genocidio se funde con la ficción de La garra escarlata - en realidad se trata de un fotograma de Vestida para matar/Dress to Kill (Neill, 1946) - (Imagen 1) y esta a su vez con la imagen del niño. Estas sobreimpresiones logran 'desvelar lo que puede haber 
detrás de esos agujeros que la acción del tiempo va abriendo tanto en la memoria personal como en las actas de la Historia' (Erice 2009). Más tarde, mediante este mismo elemento retórico, las manos sobre un piano que generan una música nocturna se convierten en una garra imaginaria, creada por el niño, a partir de la ficción cinematográfica. La frase-imagen dialéctica se convierte en símbolo. Ya en el desenlace, la digresión logra una última frase-imagen síntesis de la búsqueda que concluye, y la luz del proyector cinematográfico traspasa la imagen del niño de cinco años que se convertirá en referente de la cinematografía española (Imagen 2).
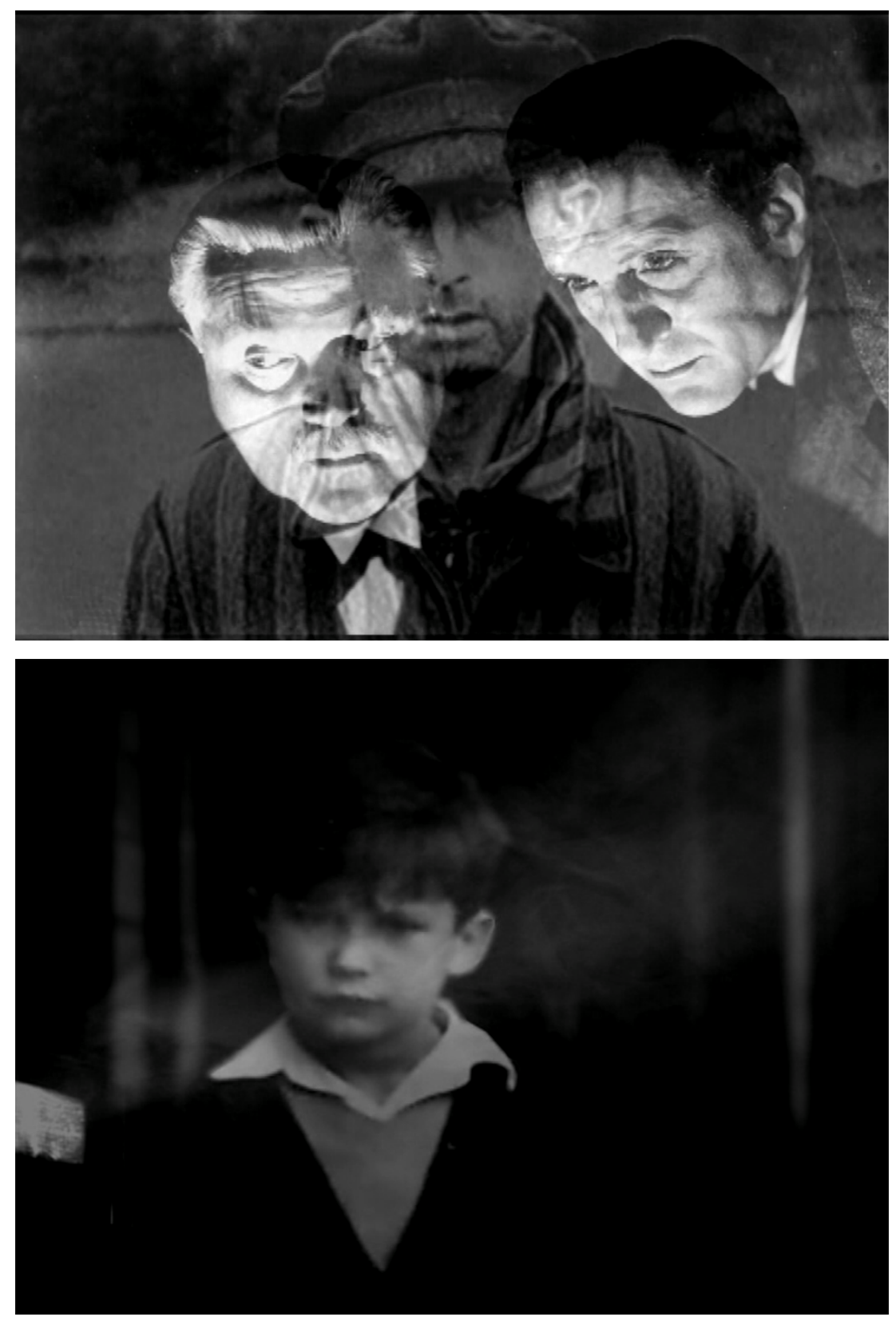

Imágenes 1 y 2: La sobreimpresión como elemento retorico de la frase-imagen. Erice, La Morte Rouge (soliloquio), 2006. España: Nautilus Films. 
En Las variaciones Marker (2007) Isaki Lacuesta crea un film-ensayo en torno al concepto de autoría artística a partir de las imágenes del cineasta francés. El autor genera un collage metadiscursivo mediante los materiales del que fue el 'docteur en collages' (Chevalier 1963: 4), entendiendo este como 'un procedimiento compositivo' en el que el montaje alcanza 'una dimensión estética en la que subyace una voluntad evidente de enfatizar la heterogeneidad de los materiales utilizados, de hacerlos entrar en conflicto, de establecer entre ellos una relación dialéctica' (García y Gómez 2009: 26). En este collage de collages el dispositivo de enunciación queda identificado, pero débilmente codificado. Siguiendo el habitual procedimiento markeriano, el yo de Isaki Lacuesta es enunciado mediante la voz off de Sergi Dies, en unos textos-relato que solo refieren su naturaleza epistolar en dos ocasiones ( $2^{\circ}$ y $3^{\circ}$ fragmento): 'Te escribo este mail desde Girona, mi ciudad natal', 'Te escribo este mail desde Buenos Aires, la ciudad partida'. La naturaleza epistolar de la obra no explicita o caracteriza en modo alguno a su destinatario. Sin embargo, la presencia latente de este dispositivo de enunciación permite a Lacuesta instrumentalizar las posibilidades de este, en el mismo sentido que lo hiciese Marker: la expresión de la subjetividad y la imaginación, el humor y la ironía para generar la reflexión. Este collage en segundo grado potencia su fragmentación y heterogeneidad mediante diferentes elementos retóricos que se instrumentalizan para crear la reflexión en torno a la intertextualidad como collage.

En el tercer fragmento, las cámaras prohibidas, Lacuesta identifica a Marker con otros cineastas, comparando sus obras mediante la pantalla dividida. Esta yuxtaposición intertextual dentro del mismo plano destruye la temporalidad y autoría de las obras mediante la cohabitación de sus imágenes, convirtiendo la Historia del cine en un collage (Imagen 3). En el quinto fragmento, el misterio Makiko, el collage intertextual se genera a través de la banda de sonido. Lacuesta sobrepone a la voz de Koumiko en Le Mystère Koumiko/The Koumiko Mistery (Marker, 1965), dando respuesta a las preguntas de Marker, la voz de Makiko contestando a esas mismas cuestiones. En el último fragmento, los trazos, el cineasta instrumentaliza el intertexto literario para generar un nuevo collage reflexivo entre los ideogramas chinos y la obra de Marker a través de la lectura de Idéogrammes en Chine (Michaux, 1975): 'Me gusta pensar que las palabras de Michaux sobre los ideogramas nos hablan al mismo tiempo de las imágenes de Marker'. El texto de Michaux toma un nuevo significado al ponerse en contacto con la obra del cineasta, como ya ocurriera en Lettre de Sibérie. 
Finalmente, señalamos dos materializaciones de esa frase-imagen definida por Rancière, la primera dialéctica y la segunda simbolista. En el cuarto fragmento, the fresh widows' variations, la frase-imagen surge de la voz off:

Hace rato que he pulsado la techa ramdon play para dejar que sea mi ordenador el que decida, que mezcle como quiera las piezas de este puzle. Yo no he montado estas imágenes, son un puro Chris Marker hecho por Chris Marker.

El texto trasforma tanto el estatuto de la imagen como el lugar del enunciador en la misma. Este pasa de ser creador audiovisual de la obra que visionamos para convertirse en observador de unas imágenes aleatorias. Surge así una frase-imagen dialéctica que no solo 'destruye la relación representativa del texto con la imagen' (Rancière 2011: 64), sino que deconstruye el relato audiovisual: la banda de sonido se convierte en comentario exterior a la obra y la banda de imagen se transforma en una disposición aleatoria cuestionando así la interpretación del espectador. En el sexto fragmento, el instante del parpadeo, surge una frase-imagen simbolista que se revela como esencia autorreflexiva de esta forma fílmica:

En las películas de Marker el parpadeo queda justo en la mitad del plano y el espectador debe apreciar y ver el instante decisivo del corte. En cada corte hay un viaje en el tiempo [...] Los parpadeos de Marker no quieren escondernos nada, quieren abrirnos los ojos.

La imagen muestra entonces el retrato de Hélène Chatelain en La Jetée (Marker, 1962); tres planos unidos por dos fundidos encadenados que muestran su despertar; un primer abrir los ojos seguidos de un parpadeo. Esta frase-imagen simbolista sintetiza la consciencia autorreflexiva del cine de Marker (Imagen 4). El destinatario no identificado de esta sugerida misiva alcanza así al espectador. 


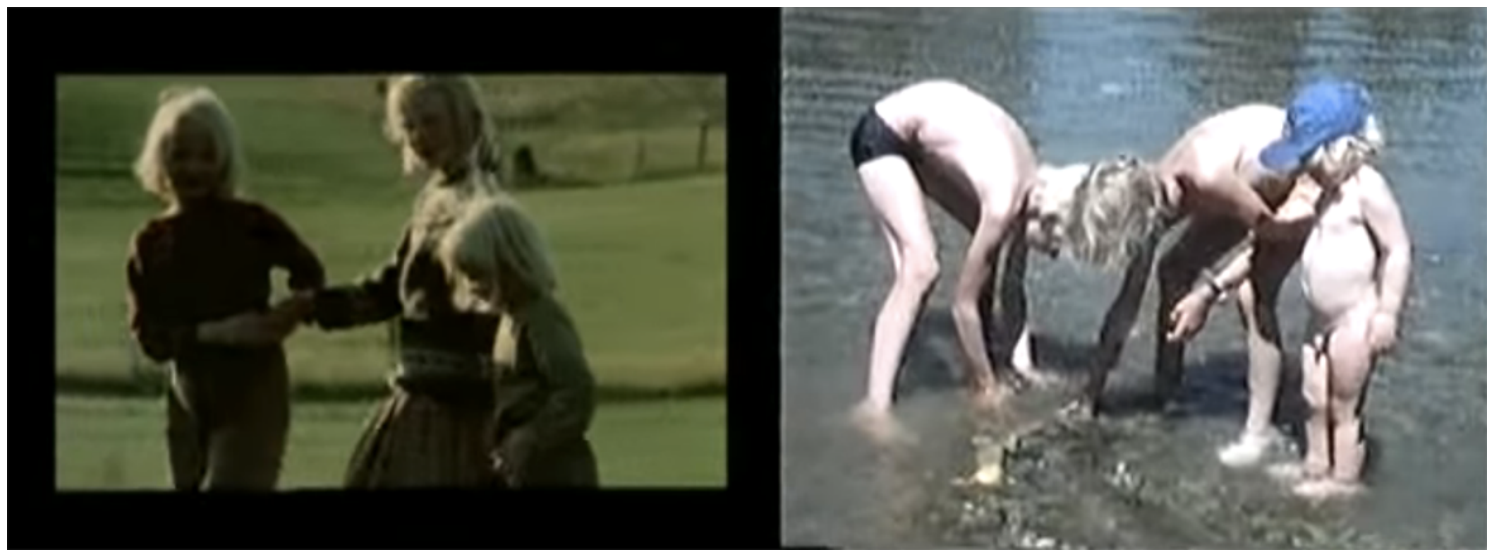

Imagen 3: Un fotograma de Sans soleil se yuxtapone con otro de Vakantie van de filmer/The Filmmaker's Holiday (van der Keuken, 1974), haciendo de la historia del cine un collage intertextual.

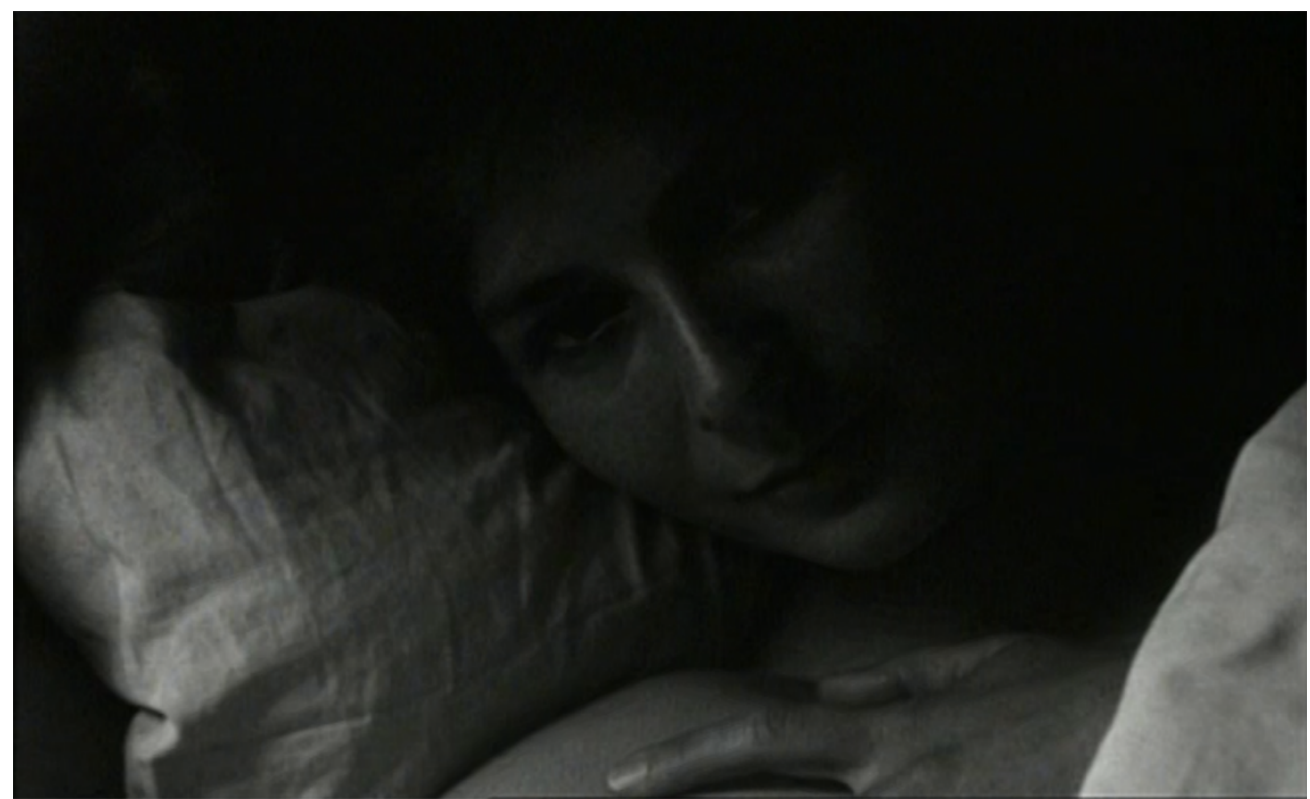

Imagen 4: La imagen de La Jetée es reutilizada para generar una frase-imagen simbolista sobre la autorreflexividad del film-ensayo. Lacuesta, Las variaciones Marker, 2007. España: Prodimag.

En Mapa (2012), León Siminiani codifica claramente el dispositivo enunciativo: un diario que abarcará dos años y medio de su vida. La obra surge de la necesidad de crear una película. La experiencia vital se pone al servicio del film: viajar a la India para filmar una película-diario. Además, este dispositivo se conflictúa mediante la presencia del diarista en dos presentes distintos: el de la grabación de las imágenes y el de la construcción de la película. La voz off de Siminiani busca entonces la espontaneidad del habla y se aleja de la lectura del texto escrito, primer elemento de una excepcional intimidad que será pieza clave de la construcción del relato. 
Este desdoblamiento del yo es la premisa que posibilita la creación de los múltiples elementos retóricos, así definidos por el cineasta: 'huellas de la ficción con las que trato de tensar narrativamente mi trabajo de no ficción' (Siminiani 2012: 91). El film-ensayo que el espectador contempla es a su vez la reflexión diarística de la creación de un film. Como indica Moure (2004: 36-37), la temporalidad del film-ensayo es la frontera entre la obra realizada y la obra por realizar. El diario avanza a través de ese desdoblamiento del presente de la enunciación y las dialécticas que genera: manipulación de las imágenes; ordenación de las mismas (flashbacks, secuencia de montaje); instrumentalización de la música, a la vez diegética y extradiegética; etc. Aparece además un innovador elemento enunciativo: el Otro. Una conciencia del autor, igualmente enunciada en voz off e igualmente desdoblada en ambos presentes, que lo interrumpe en diferentes momentos, cada vez que considere que la empresa de crear el film está en riesgo. Esta segunda voz se convierte en un nuevo elemento 'retóricoemocional' (Català 2012: 74). Su primera intervención, durante las imágenes de Varanasi, releva esta presencia desdoblada:

Bueno, ya está bien con el tema de la muerte, que ya lo hemos captado. A ver, funde a negro. Y ahora abre después de haber salido el sol. Eso [montaje]. Móntate, móntate en el bote. Y graba el Ganges sí, pero al amanecer. No, a los crematorios no, mejor río abajo [filmación].

En su segunda intervención, el Otro le recrimina la grabación de una mujer desnuda en las calles de Delhi. Siminiani instrumentaliza entonces el intertítulo como expresión del mutismo en el que se ha sumido tras las críticas del Otro. El silencio se mitiga al inscribir el texto sobre la imagen, para a continuación volver a surgir la voz off. Su tercera intervención, una nueva recriminación sobre la indecisión del protagonista, va seguida, de nuevo, del intertítulo con el que Siminiani se comunica con el espectador. El autor decide en mitad del viaje, y a mitad del film, convertir el diario en una película de amor. Tras el fracaso amoroso, la búsqueda vital se convierte nuevamente en búsqueda argumental para concluir el film.

La jornada de campo con Ainhoa evidencia de nuevo ese impulso controlador por el cual la vida es un escenario a ordenar mediante la mise en scène. Se produce entonces uno de esos momentos que escapan a la puesta en escena prevista: las manos de Ainhoa ofreciendo moras, como anteriormente había ocurrido con el del niño de Leh, 
reclamando el plano frente a la vaca filmada (Imagen 5). La necesidad de domesticar la realidad para responder a las necesidades de la creación fílmica son el epicentro de la obra y de algunas de sus frases-imágenes. En Delhi, las imágenes de los edificios racionalistas se desvelan como ejercicio de control al restituirles su sonido directo tras la confesión del autor: 'la vida bulle bajo los límites del encuadre, pero yo la evito, centrándome en los edificios'. La panorámica vertical sobre el edificio, con la variación del volumen de su sonido directo, se convierte en elemento retórico-emocional que desvela además su 'función epistemológica' (Català 2012: 75).

El film, el diario, no concluye, su continuación se cifra en la conclusión del inacabado viaje a la India, hacia el que parte Siminiani. La combinación de las diferentes enunciaciones textuales - off de Siminiani, off del Otro, intertítulo y subtítulo - va acompañada de la progresiva pero tímida aparición del autorretrato. Siminiani permanece tras la cámara durante el viaje a la India, para ir surgiendo en la imagen en la segunda parte de la obra: primero como sombra ansiosa en la calle, sumido en la penumbra de su casa después, hasta autorretratarse tras el accidente, para dejarse filmar por Ainhoa en el desenlace, renunciando así al control de la imagen y de un relato inconcluso (Imagen 6).

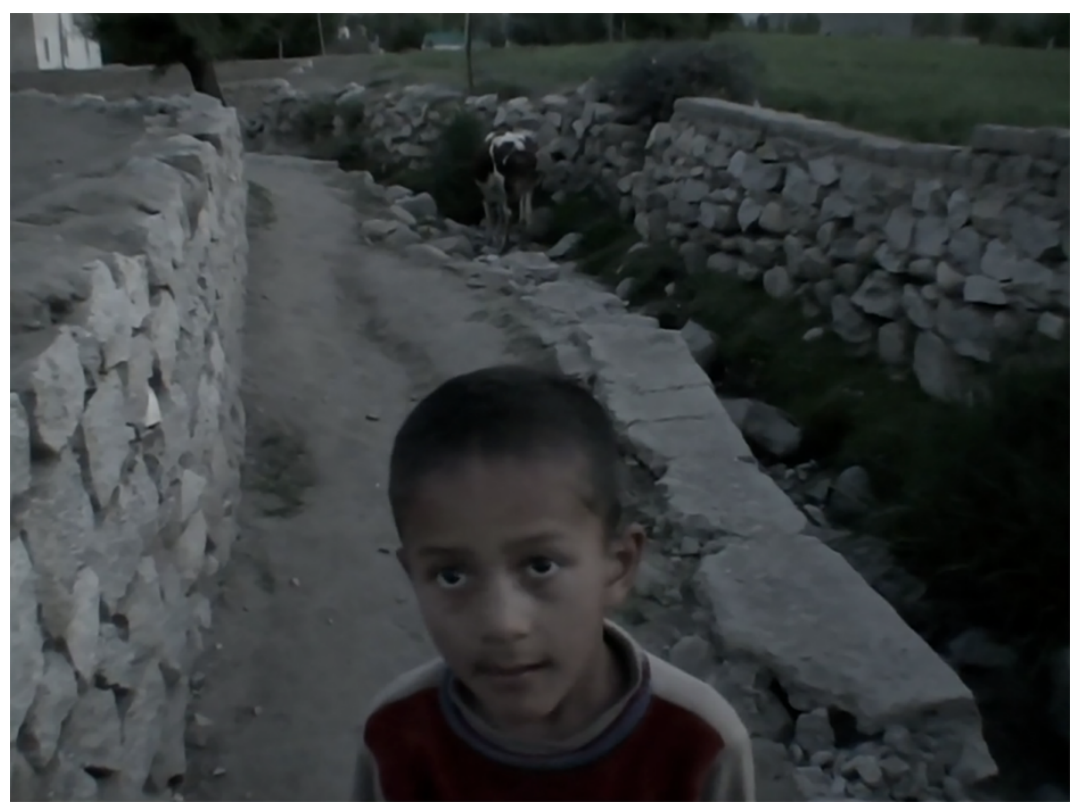




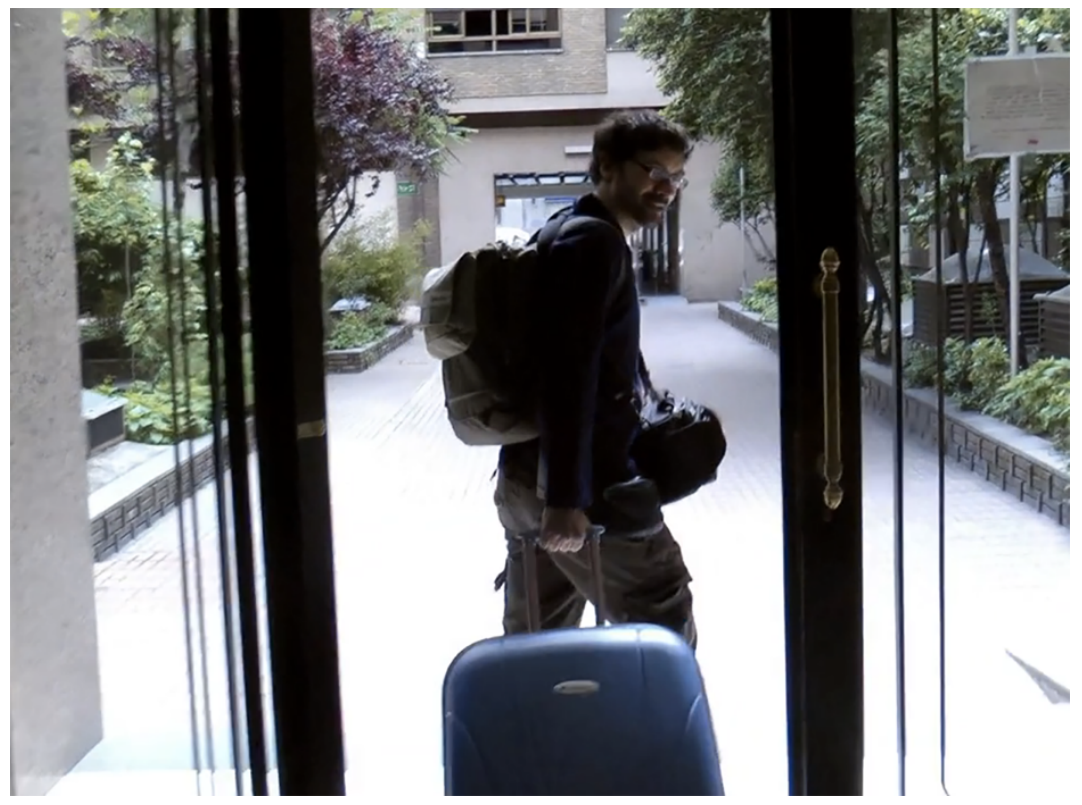

Imágenes 5 y 6: El film-ensayo transita desde la necesidad de control de la obra por realizar a la aceptación de su inconclusión. Siminiani, Mapa, 2012. España: Avalon, Pantalla Partida Producciones.

\section{Subtítulos: Ficcionalización-desautomatización y desintensificación}

El colectivo Los Hijos realiza el desplazamiento desde la subjetividad de sus voces fuera de campo en El sol en El sol del membrillo (2008) al subtítulo sobre la imagen en Los materiales (2009), instrumentando además el diálogo como dispositivo de enunciación. El film enfrenta la realidad silente que recoge la cámara con los supuestos diálogos de los realizadores que la están registrando. La transformación de la voz en texto debilita la presencia de la subjetividad al tiempo que la desplaza hacia la ficción:

Desprovistos de entonaciones, timbres de voz o rostros a los que incorporarlos, estos textos flotantes pasaban a tener un carácter casi neutro, extremadamente maleable. Una maleabilidad multiplicada con el pronto descubrimiento de que esos diálogos transcritos podían ser complementados, matizados y transformados por otros textos absolutamente inventados por nosotros en la sala de montaje. (Los Hijos 2012: 120)

Los fragmentos de conversaciones reales, manipuladas o inventadas en forma de subtítulos dotan además al fuera de campo de una nueva y muy relevante presencia, totalmente desconectada de las imágenes que se graban y, por tanto, entrando en conflicto con ellas. Frente a la preconcebida atención de la mirada del cineasta sobre el 
paisaje, en busca del momento revelador, Los materiales destruye este apriorismo del cine observacional para mostrar el rechazo, la indiferencia, el aburrimiento, incluso la burla o la falta de respecto.

El pensamiento fílmico, la frase-imagen, surge entonces de la dialéctica entre una imagen silente que el espectador descodifica de forma automática bajo el paradigma del cine observacional y unos subtítulos que dinamitan dicha lectura mediante tres niveles que provocan un progresivo distanciamiento y extrañamiento: la imagen filmada; la realidad en la que se produce la filmación; realidades ajenas al trabajo que se está realizando (Imágenes 7 y 8). La destrucción del discurso automatizado se convierte entonces en la mostración de la construcción material del mismo. La de la búsqueda del encuadre, la de grabación del sonido, la de las constantes decisiones sobre el qué filmar, cómo trabajar: 'La película ahonda en la inscripción de los procesos de construcción del discurso cinematográfico', generando el 'cuestionamiento radical de los sistemas de trabajo' (Pedro 2012: 111-12). Los materiales revela la fuerte automatización de la lectura de estas imágenes por parte del espectador. El cuestionamiento de las mismas se produce en todas sus vertientes: el estatismo de la cámara; los encuadres y sus duraciones; el trabajo en torno al silencio y el sonido directo; los motivos naturales; y también el elemento testimonial humano. Las subjetividades de los autores, ficcionalizadas a través de los subtítulos, se convierten en herramienta de cuestionamiento de la observación documental.

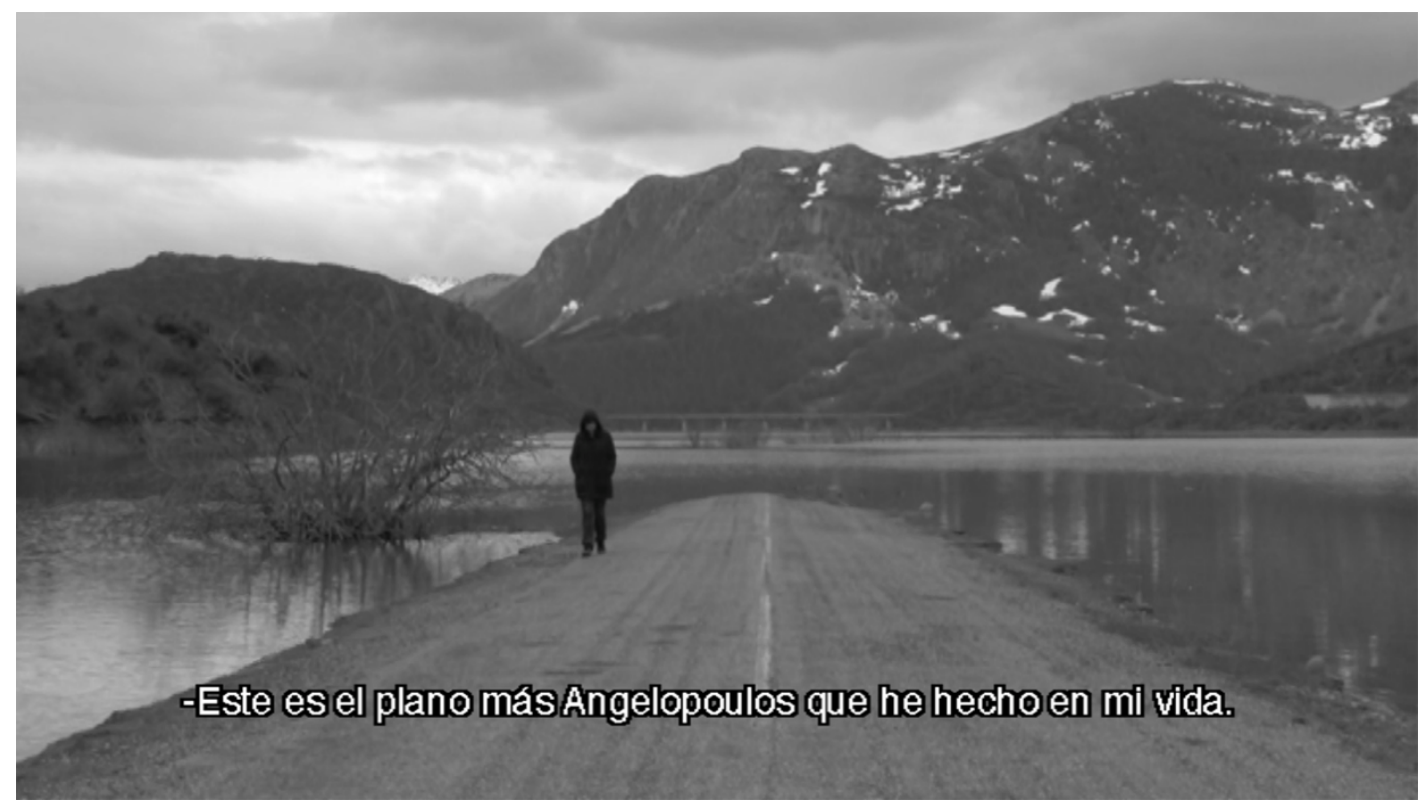




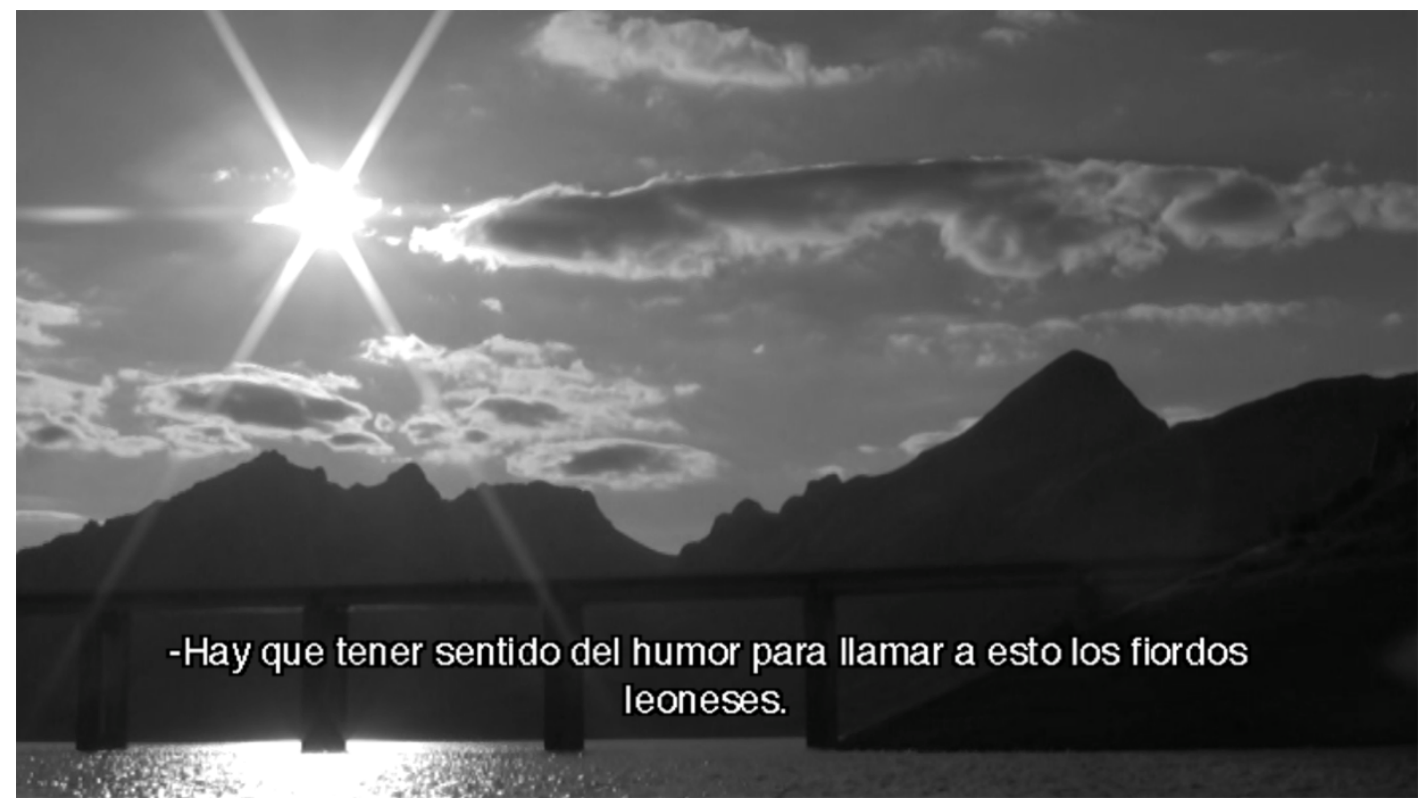

Imágenes 7 y 8: Los subtítulos entran en conflicto con la significación apriorista otorgada a las imágenes. Los Hijos, Los materiales, 2009. España: Colectivo Los Hijos.

En Color perro que huye/Color Runway Dog (2011) Andrés Duque instrumentaliza igualmente el subtítulo para coadyuvar a lo que Fernández Labayen y Oroz denominan 'efecto de desintensificación', con el que 'articular de forma oblicua su subjetividad' (2013: 107). A la ordenación de imágenes extraídas de sus 'cajas de memoria llamadas Qucktime', al ejercicio de relectura de las imágenes almacenadas, el cineasta añade nueve textos en forma de subtítulos que confieren una dimensión emocional, poética o filosófica a la reflexión sobre la naturaleza de la memoria contemporánea en relación a la imagen. Además, el cineasta incluye otros tantos intertítulos con los que ofrecer una personal e íntima noción de ordenación del discurso al tiempo que incide en su fragmentación, también la de su título: Apetite for destruction; Huye: Color; Neverlands; Peterpanes; Caicedo; Willmore; Campanillas; Perro.

Los subtítulos materializan una suerte de anotaciones y microrrelatos sobre la imagen en torno a diferentes motivos: la interacción virtual a través de Internet, la realidad marginal de la ciudad de Barcelona o el recuerdo de la ciudad natal. En el primer caso (tercer texto), las palabras del cineasta se añaden a la imagen de una de esas interacciones virtuales con una mujer: 'Internet no es, ni mucho menos, una utopía. Pero parece que resuelve un problema fundamental. El dilema de cómo vivir juntos, poniendo en común distancias' (Imagen 9). Su reflexión sobre estas relaciones virtuales logra 'dibujar un tenue sostén comunicativo, suficiente para conectar los cuerpos y experiencias del director, los internautas anónimos que aparecen en pantalla y los 
espectadores' (Fernández Labayen y Oroz 2015: 188). El cuarto texto, un microrrelato sobre Barcelona, se constituye en elemento fundamental de 'una medida puesta en escena' (Fernández Labayen y Oroz 2015: 188) en el que la mirada del autor va adquiriendo espesor sociológico, antropológico, filosófico:

Bajando por la Rambla de Santa Mónica, a la izquierda, se produjo una extraña erosión. Es un agujero hecho por prostitutas que durante años han esperado ahí a sus clientes. Ponemos distraídamente nuestros pies y descubrimos en esas huellas uno de los momentos vivos de Barcelona. Uno de los pocos que podemos admirar.

Estos subtítulos, fragmentarios y tangenciales, no sostienen ya el peso de la expresión de la subjetividad pero sin duda responden a la noción de digresión, un 'vagabundeo del pensamiento' (Ménil 2004: 101), que genera interpretaciones alegóricas de la imagen: 'La identidad del cineasta se presenta mediada por las tecnologías de representación [...] generando simultáneamente un espacio de reflexión desde el que ejercer la crítica cultural en un contexto cambiante' (Fernández Labayen y Oroz 2013: 103). Al abordar el recuerdo íntimo, el de su perro Román, la imagen se congela, se repite, se ralentiza, se manipula. Junto a ella, dos textos narran su muerte y el sentimiento del autor: 'A veces me lo imagino volando y me estremezco. Veo una mancha borrosa que cae al vacío. Una mancha difícil de describir pero que definitivamente es también un color' (Imagen 10). La emoción causada por la ausencia parece necesitar el trabajo sobre la imagen para posibilitar el recuerdo de lo desaparecido. La reflexión ensayística se focalizada así en el espacio emocional a través de la manipulación de la imagen. Este esbozo final sobre la imagen-emoción será el motivo central de su siguiente obra, Ensayo final para utopia/Dress Rehearsal for Utopia (2012), que analizaremos más tarde. 

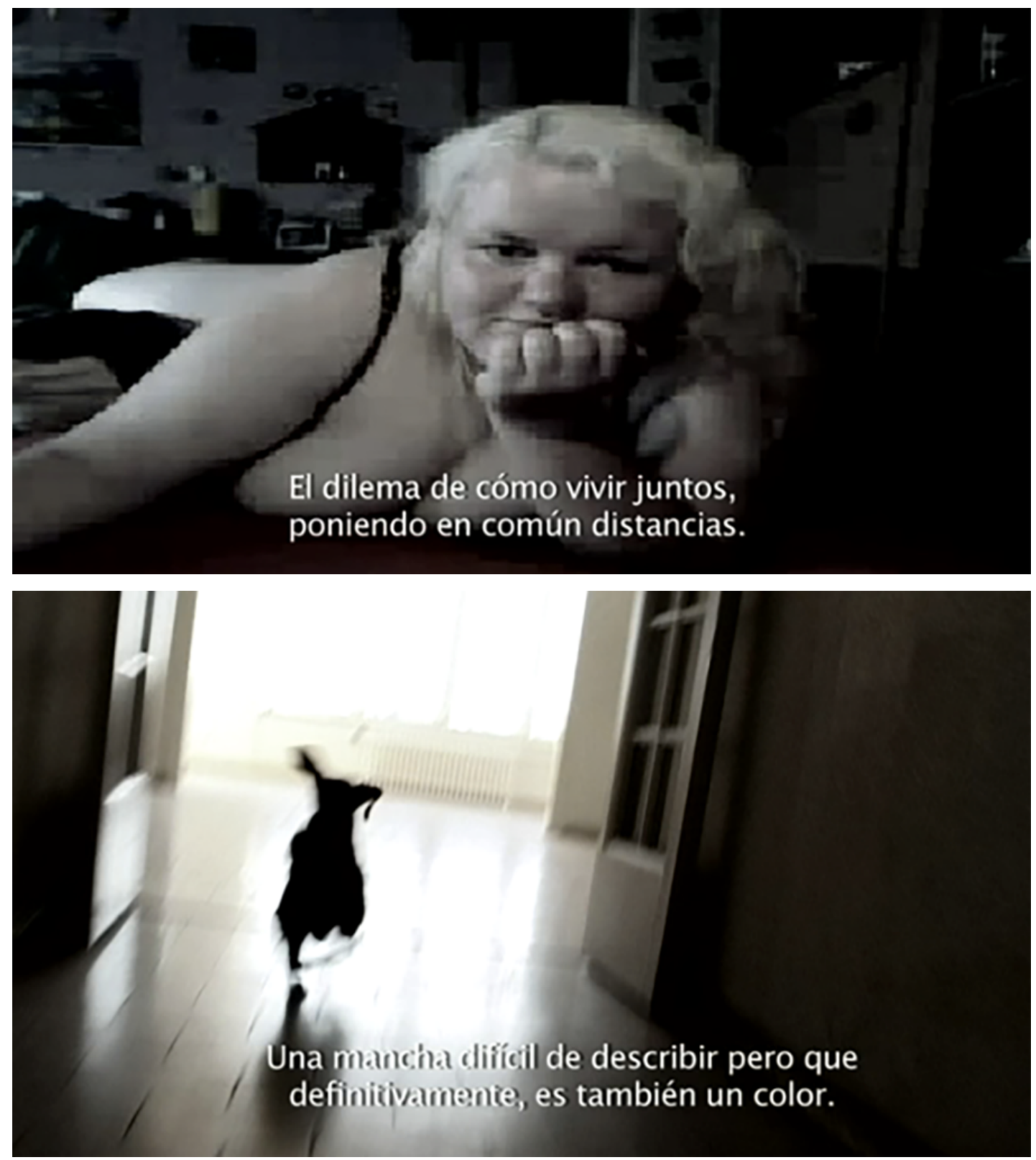

Imágenes 9 y 10: Los subtítulos proponen la digresión ensayística en torno a las imágenes utilizadas. Duque, Color perro que huye, 2012. España: Hamaca Media \& Video Art.

\section{Intertítulos: Objetivación y ficcionalización-sustracción}

Frente a los subtítulos anteriores, José Luis Guerin crea Dos cartas a Ana (2011) a partir de la inscripción del texto sobre la pantalla en forma de intertítulo, que se alterna con las imágenes en B/N. El dispositivo epistolar se codifica con claridad. Dos misivas dirigidas a Ana Portinari y fechadas en noviembre de 2010. Sin embargo, este destinatario conocido no modifica el contenido de una misiva que construye una reflexión acerca de la creación artística: pictórica, literaria, coreográfica y fílmica. La enunciación a través del texto escrito implica una clara racionalización de la expresión 
de la subjetividad, donde desaparece la emoción subjetiva para reafirmar la exposición clara de un razonamiento. Una reflexión sobre el arte como proceso de 'imaginar la imagen'; una imagen desaparecida que la creación artística materializa de nuevo, a partir del hecho de que no se conserva ninguna obra de Zeuxis, pintor griego de la época clásica. Las dos cartas se generan como dos momentos de la reflexión. La primera ofrece la exposición teórica y la segunda la puesta en práctica de la anterior.

El primer texto epistolar expone la identificación entre el lienzo pictórico y la pantalla cinematográfica, mientras que la imagen materializa esa idea haciendo del lienzo una suerte de pantalla translúcida donde se proyecta la mano del artista y su pincel. El cuadro Zeuxis eligiendo a sus modelos... (François-André Vincent, 1786-96) hace reflexionar a Guerin sobre la figura del cineasta como heredero de esos pintores clásicos. Sobre la imagen pictórica surge entonces unas sombras en movimiento, el espectro cinematográfico sobre la pintura que se prolongará a lo largo de toda la misiva. El juego de sombras y luces sobre el cuadro llega a iluminar el lienzo de Zeuxis como si de una pantalla cinematográfica se tratara. Guerin crea así una nueva imagen que sintetiza la idea expuesta en el texto, más aún, que descubre el instante de su revelación. La carta concluye con la formulación de la tesis que materializará en la segunda misiva, al hablar de Plinio: 'Sus descripciones de cuadros desaparecidos inspiraron a los pintores del Renacimiento. Descripciones de pinturas que generan nuevas pinturas. Como imágenes sin imagen [écfrasis]. Palabras fecundas que generan imágenes. Imágenes para imaginar. Es sólo una idea' (la cursiva es nuestra).

La segunda misiva creará la imagen fílmica de una primera imagen pictórica desaparecida, descrita por Plinio: la de la dama de Corinto. Se genera así una écfrasis invertida, del texto literario al fílmico, a través de la danza. Para llevar a cabo este proceso de pensamiento, el cineasta-remitente epistolar necesita inscribirse en la enunciación: 'Te escribo desde el Parnaso, a donde he acudido en busca de oráculo para acometer tu encargo'. Esta inscripción textual se hace a continuación imagen y la sombra del cineasta se proyecta sobre Corinto, paseando por el espacio y filmando la tierra a su paso. De su imaginación surge entones la imagen de la dama de Corinto. Su encarnación fílmica comienza con la imagen de las colas iniciales de la proyección cinematográfica, enfatizando la naturaleza fílmica de lo que sigue. La vela se revela entonces como el instrumento generador de las sombras, como símbolo de la luz cinematográfica que posibilita la imagen en movimiento. A continuación, las sombras de dos figuras, masculina y femenina, se encarnan en el mismo plano, pasando de la 
proyección a su materialización. Ella mira a cámara, rompiendo así su propia ficción al interpelar al autor y al espectador y revelando la autorreflexividad fílmica. Se mueve y la sombra masculina responde a esos movimientos. Existe una comunicación gestual entre ambos, la del vínculo entre pintura y cine: 'el movimiento de un trazo para fijar una sombra'. Una nueva mano femenina crea entonces el trazo del paisaje fílmico: Corinto, el Monte de Afrodita. Se retoma el movimiento y la dama vuelve a convertirse en sombra, moviéndose ahora junto a la sombra inmóvil del ausente, que se transforma en pintura, en fresco del templo de Apolo (Imágenes 11 y 12). Frente a las frase-imagen dialéctica y simbolista expuestas por Rancière, podríamos decir quizá que la generada por Guerin alcanza ese límite de lo indiscernible mediante una suerte de frase-imagen síntesis, donde la reflexión fílmica tiene como resultado la encarnación en la imagen de una reflexión teorizada mediante el texto. Tras ella, el cineasta continúa su paseo por las ruinas, convirtiéndose a sí mismo en otra sombra sobre ellas.

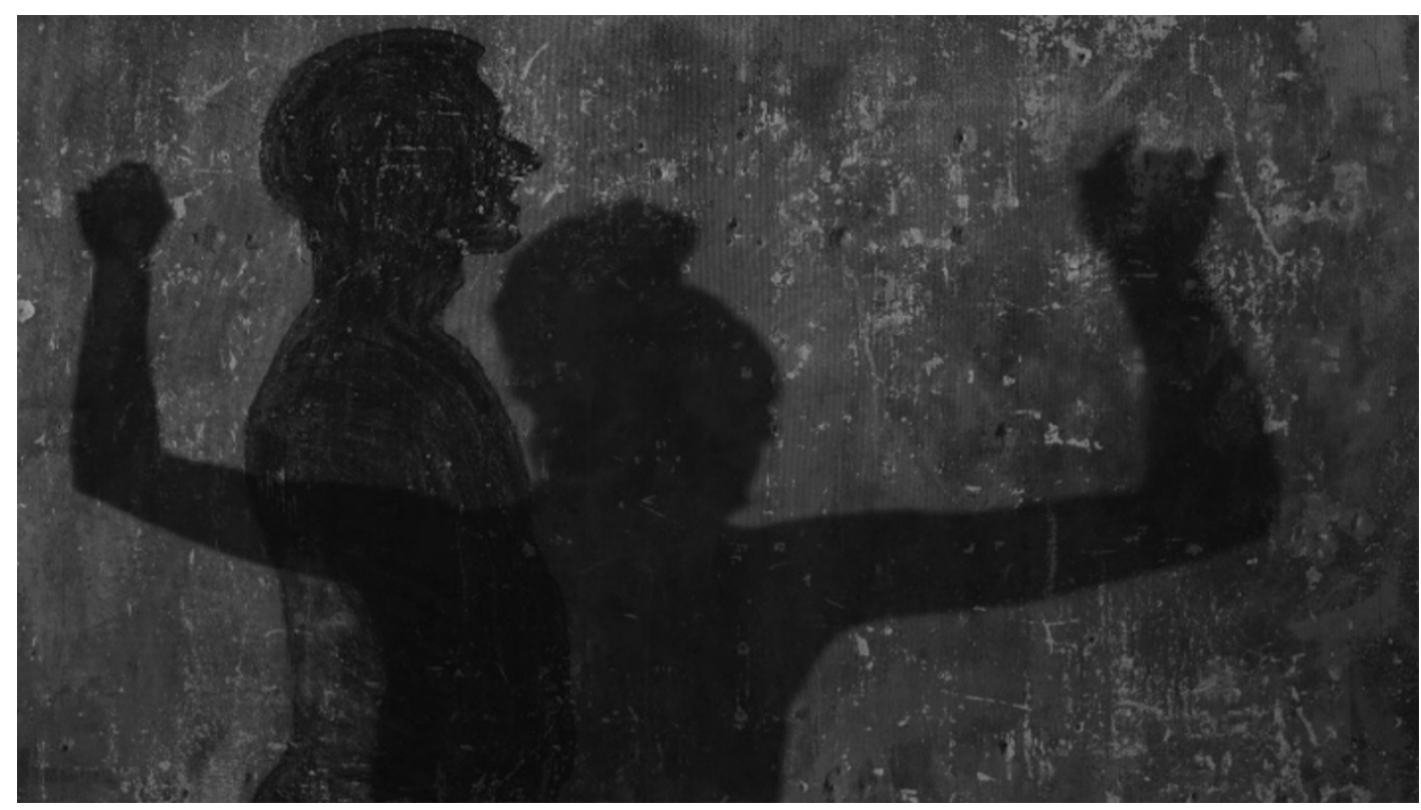




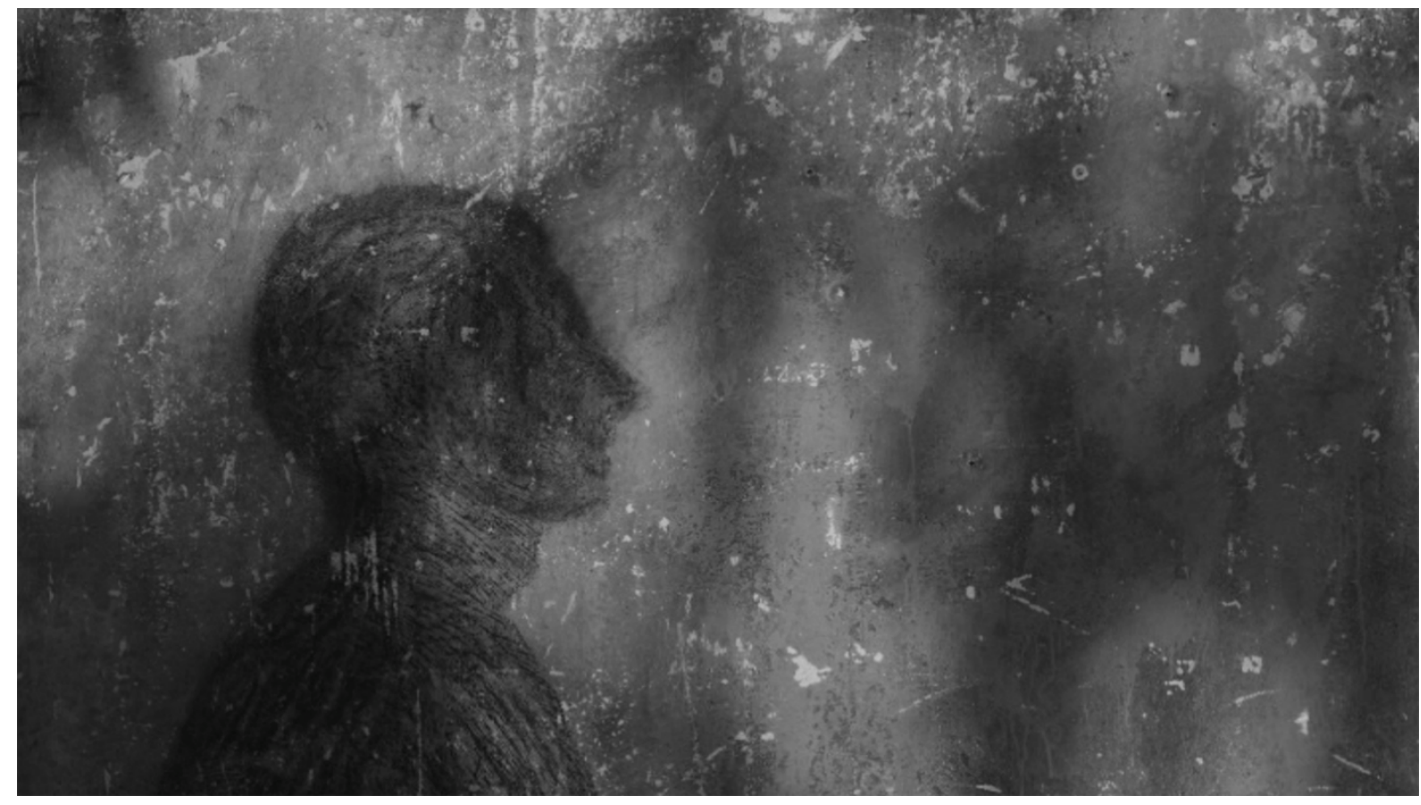

Imágenes 11 y 12: La sombra en movimiento del bailarín se convierte finalmente en pintura sobre la piedra. Guerin, Dos cartas a Ana, 2011. España: Museo de Arte Contemporáneo Esteban Vicente.

La casa Emak Bakia/The Search for Emak Bakia (2012), de Oskar Alegria, establece su dispositivo de enunciación a partir de una cita de Man Ray, con la que se inicia el film: 'Esta obra está realizada por una persona y dirigida a otra persona, a usted, que está aquí'. A partir de esta premisa de mensaje del autor al espectador, Alegria enuncia la obra fílmica a través de un extenso texto que se intercala a lo largo de toda la obra en forma de intertítulo. Su contenido constituye las notas de su investigación, donde la enunciación neutra en primera persona da a conocer los acontecimientos sobre la misma, sin que surja la expresión emocional o íntima del autor. Este intertítulo, sin embargo, alcanza una significación nueva al enfrentarse a los intertítulos de la obra Les Mystères du château du Dé (1929), también de Man Ray. Se produce entonces una primera dialéctica entre las vanguardias y el cine contemporáneo: entre el intertítulo analógico y el digital, entre poeticidad y neutra información, entre la necesidad del texto en el cine mudo y elección del mismo en la actualidad contemporánea.

La reflexión que genera el film gira en torno a la relación intertextual entre Emak Bakia (Ray, 1926) y la búsqueda que realiza La casa Emak Bakia. Una libre digresión sobre la obra artística y su reinserción en la realidad en la que fue creada: 'demostrar la capacidad del cine para recuperar la vida sumergida por el paso del tiempo' (Echart 2013: 53). De esta forma, el film-ensayo intenta descifrarla, reinterpretarla, reconstruirla, recrearla, compararla, revelando todas las resonancias que puedan surgir 
entre aquella ficción y esta realidad, entre aquella vanguardia y la contemporaneidad. La evidente naturaleza intertextual de la obra instrumentaliza diversos elementos retóricos. En primer lugar, Alegria pone en contacto diferentes momentos de la obra de Man Ray con la realidad actual mediante su yuxtaposición en planos continuos. Se revela así la trasformación del espacio y el tiempo extradiegético, exterior a la obra: la mostración de la playa en ambas épocas, de los luminosos de la ciudad. o del baile, entre el Charleston y la danza vasca. En este último, el cineasta instrumentaliza un nuevo elemento, generando racord de continuidad entre el vaso que levanta el bailarín y el que bebe Man Ray, y creando así un nuevo juego entre ambos espacios. En segundo lugar, el cineasta recrea diferentes planos de Emak Bakia y los expone de manera simultánea junto al original mediante la pantalla dividida: el mar; el giro del horizonte; el balcón de la casa; las imágenes de la protagonista femenina; o las mujeres durmientes. En este caso, el contacto directo de ficción vanguardista y recreación contemporánea revelan el vínculo intradiegético entre no ficción y ficción; se contaminan mutuamente, desplazan su significación hacia el otro lado de la pantalla. Este desplazamiento se convierte en fusión en dos ocasiones mediante la sobreimpresión de ambas imágenes: los peces y los pies que descienden del automóvil. Ficción y no ficción dan paso entonces a la materia onírica, al territorio en el que ambas naturalezas pueden confundirse.

La relación intertextual se produce también entre los intertítulos de Man Ray y las imágenes de Alegria. En el primer procedimiento, el intertítulo adquiere una nueva significación en relación a la obra en la que se inserta: se dirige al guante de plástico llevado por el aire; sitúa al cineasta en un nuevo espacio de búsqueda; lo define, convertido en intruso que espía el sueño de los cerdos; o describe el encuentro azaroso del cineasta con la princesa rumana. En un segundo procedimiento, el cineasta crea una nueva imagen que materializa una nueva significación del intertítulo de Man Ray: étoile du jour, Minerve casquée, Ève sous-marine (Imágenes 13 y 14). 


\section{Ève sous-marine.}

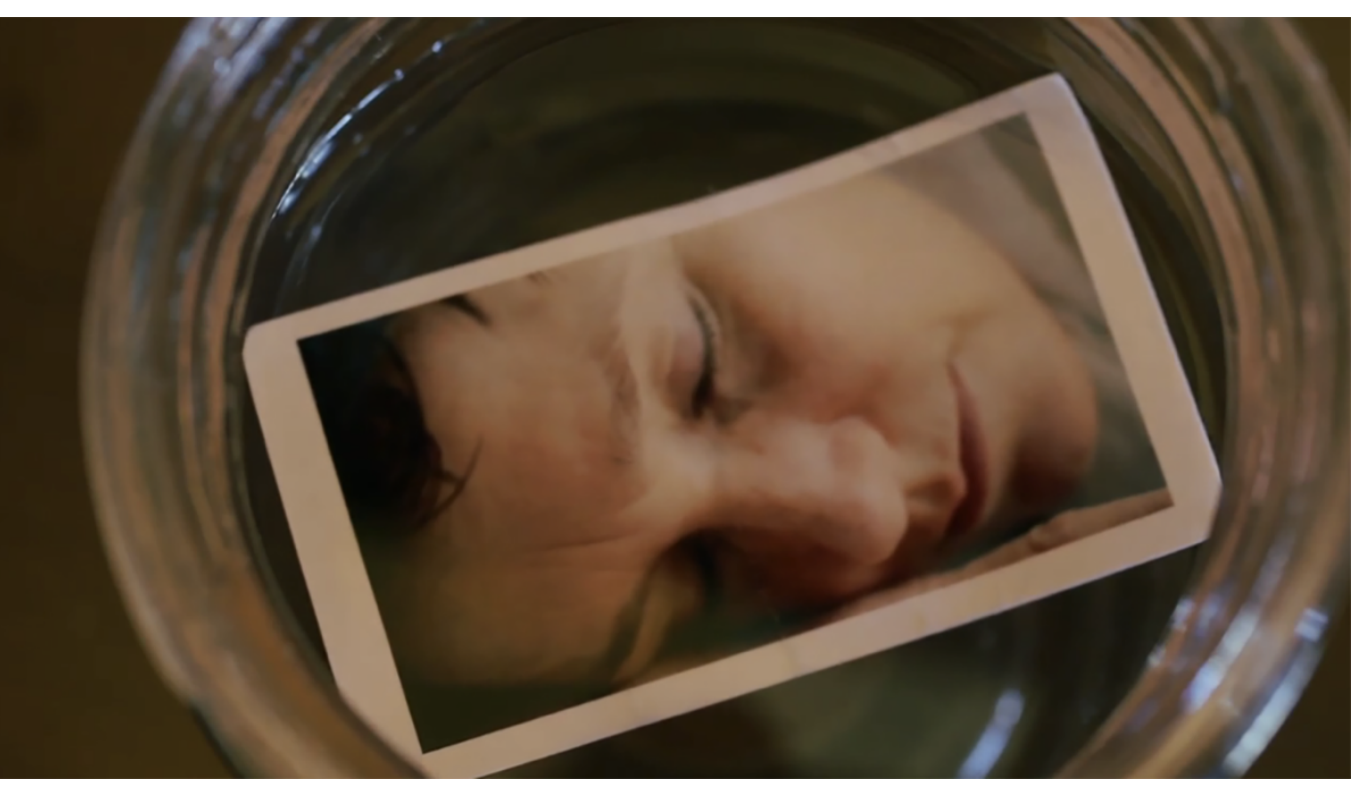

Imágenes 13 y 14: Alegria crea un nuevo referente visual para el intertítulo de Man Ray. Alegria, La casa Emak Bakia, 2012. España: Emak Bakia Films.

La casa Emak Bakia se construye también como una reflexión en torno a la relación de estos espacios con las posiciones de autor y de espectador, como indicaba la cita inicial de Man Ray, incidiendo en la naturaleza dialogística del film-ensayo. Del autor Man Ray a los espectadores, entre los que se encuentra Alegria, y de este último de nuevo a los espectadores. Y como sustrato temático de todo ello, surge la reflexión sobre la desaparición y la lucha contra el olvido, con dos frases-imágenes que la sintetizan. En la primera, sobre la fotografía funeraria de Man Ray corren las gotas de lluvia que convierten su imagen en fugaz arte de su propia obra. En la segunda, la imagen final de la placa de Emak Bakia, designando al fin la casa encontrada, recupera el nombre del olvido. 
En Invisible (2012), Víctor Iriarte instrumentaliza el intertítulo para generar un espacio sin imagen que simultanea la narración de ficción - una película de vampiros y de no ficción - la historia de amor/desamor entre el autor y la protagonista: la músico Maite Arroitajauregui, Mursego - mediante un diálogo escrito entre ambos que incluye también el metadiscurso fílmico. La voz off del autor surge únicamente en dos ocasiones y finalmente escuchamos un mínimo diálogo telefónico entre los protagonistas.

Los desdoblamientos enunciativos de los intertítulos (donde ambas voces se distinguen mediante el color de los mismos: blanco para Víctor, amarillo para Maite) se alternan con la imagen visual de Maite trabajando en el estudio de grabación, filmada con cámara fija, sin que se produzca interacción alguna con el dispositivo audiovisual. La reflexión fílmica se genera entonces entre el retrato de la artista trabajando, los intertítulos en sus diferentes naturalezas, y la imagen en negro como espacio mediador entre ambas. Sobre esta última surge el sonido de la construcción de las canciones en las que trabaja Maite en la imagen, y también diferentes sonidos en relación a las enunciaciones del texto. La pantalla en negro es el terreno sobre el que se construye la obra, la imaginada por cada espectador; es también el lugar donde convergen narración, diálogo y mostración.

Los primeros intertítulos determinan ya la naturaleza y complejidad de esta reflexión: 'Al final de esta película morimos' (voz del autor); 'Nadie conoce $t u$ secreto' (las cursivas son nuestras). Las palabras de la protagonista aparecen aquí entrecomilladas, citadas, mientras que en el resto del film aparecerán con el guion del diálogo. La voz off del autor surge entonces para convertir el diálogo en narración pasada:

Te dije que estaba preparando una película de vampiros y que me gustaba que hicieras la banda sonora. Tú me preguntaste si era una película triste y yo te dije que un poco. Después me preguntaste si era una película sobre nosotros y yo te dije que sí.

Al mismo tiempo, los intertítulos muestran el diálogo directo sobre ese futuro film. La obra se revela ya como intertexto contemporáneo de diferentes film-ensayos de la modernidad: Lettre de Sibérie, donde se dedica la narración al vous epistolar; Letter to Jane, otra carta que, como el film de Iriarte, surge de la pantalla negro; Le Camion 
(Duras, 1977), donde la obra se genera a partir del diálogo en imagen entre cineasta y autor sobre el posible film. El propio autor expresa la naturaleza epistolar de la obra: 'a mí me interesa mucho la primera persona y la reivindico. Esta película tiene algo de carta abierta [...] quería contar mi particular canción de amor/desamor así, en primera persona' (Ortiz 2014).

Este intertexto contemporáneo se genera a partir de la sustracción del cine contemporáneo que teoriza Antony Fiant (2014) - de la imagen; de la continuidad narrativa - y de la complejización de la enunciación - primera persona del autor, diálogo de los protagonistas-autores, tercera persona de la narración. El film genera así la reflexión sobre la creación musical de Maite y sobre la construcción de una obra audiovisual, desentrañando para ello la memoria de una relación amorosa. Tras otro intertítulo: 'Es una película de amor', se muestra por primera vez el rostro de la protagonista (Imágenes 15 y 16).

Es una película de amor 


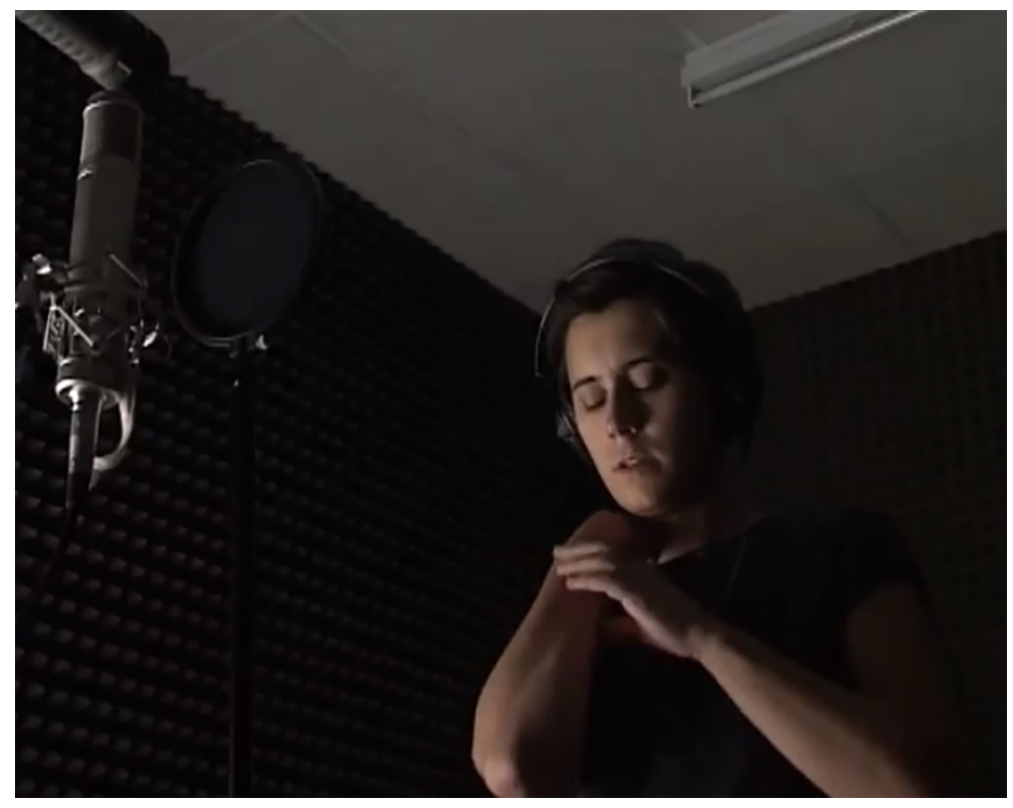

Imágenes 15 y 16: Los intertítulos de la narración y el diálogo se yuxtaponen a la imagen del trabajo musical de Maite Arroitajauregi. Iriarte, Invisible, 2012. España:

KREA Expresión Contemporánea Vital Kutxa, Cajaconcosasdentro

El desenlace de la película va a corroborar su hipótesis creativa. Por primera vez el diálogo entre ambos autores cobra voz, y con ella identidad, al proferir sus respectivos nombres. Sobre la pantalla en negro, escuchamos el tono del teléfono, la voz off de él: 'Hola, Maite', y la respuesta de ella: 'Hola, Víctor'. La conversación telefónica prosigue de nuevo a través de intertítulos. A continuación, la conclusión de la obra genera una imagen-continente capaz de asumir todo el contenido no visualizado del film habitando un único plano. Varias imágenes en $8 \mathrm{~mm}$ muestran un bosque nevado en el que se halla un cuerpo sobre la nieve: 'De repente, gracias al reverse (gracias por tanto al cine) el cuerpo cobra vida, se incorpora y, marcha atrás, camina de espaldas hacia la cámara, borrando sus huellas. La resucitada no es otra que la propia Maite' (Vilches 2014: 44). El último plano nos muestra el rostro de Maite mirando a cámara, ofreciéndonos así el contacto visual entre el autor y la protagonista y, a través de él, también con el espectador. Ficción y no ficción cristalizan en un mismo plano, en una única mirada.

\section{Desaparición del texto: Intensificación emocional y borrado}

Con la desaparición de todo tipo de texto, la subjetividad ensayística pierde una de sus vías de expresión, que entonces se produce de forma directa solo a través de la autoría de las imágenes, como filmeur de las mismas. Esta presencia también puede desaparecer 
en favor del uso del found footage, lo que irá dibujando un progresivo borrado de la subjetividad.

En Ensayo final para utopía (2012), de Andrés Duque, la desaparición del texto en favor, principalmente, del silencio, y la autoría de imágenes de absoluta intimidad, donde el autorretrato sigue teniendo una presencia fugaz, generan una intensificación emocional de la subjetividad. Grabado íntegramente con un teléfono móvil, el cineasta muestra imágenes de un viaje a Mozambique y las combina con las de los últimos meses de vida de su padre. La reflexión se focaliza en el espacio emocional. Sobre cómo convertir la imagen en emoción en torno a dos sentimientos opuestos: la celebración de la vida - los bailes filmados en Mozambique - y el dolor de la pérdida el fallecimiento del padre. La obra ofrece una primera manipulación general de la imagen: 'La aplicación D-Noise que difumina los contornos y satura los colores genera un efecto de extrañamiento que acaba confiriendo a las imágenes la consistencia tenue y efímera de los sueños' (Fernández Labayen y Oroz 2013: 111). En nuestra opinión, este nuevo estatuto de la imagen se acerca más a lo memorístico que a lo onírico, a la naturaleza de la imagen como recuerdo emocional. Estas imágenes memorísticas están asociadas también, en la mayoría de los casos, a la ausencia de sonido, produciéndose así una estilización y despojamiento general de la imagen. Partiendo de esta premisa, la reflexión sobre la emoción se desarrolla en dos direcciones opuestas. La emoción celebratoria, la de la vitalidad existencial, se trabaja a través de la manipulación de la imagen: ralentización, congelado, vibración, etc. La emoción en torno a la muerte y la pérdida, sin embargo, redundan en ese despojamiento inicial, en la desnudez de la imagen en la que se hace aún más patente la ausencia de sonido. Esta ausencia se convierte en una suerte de materialización de la conmoción emocional, de la impotencia ante la pérdida. Ya en la conclusión de la obra, ambos procedimientos se encuentran: la manipulación de la imagen, y con ella la expresión emocional, se convierte en herramienta de superación del duelo. La manipulación de la imagen que hace levitar y vibrar a las figuras humana en la calle (Imagen 17) lograría recuperar un recuerdo liberado de la pérdida (Imagen 18), el del padre antes de la enfermedad. 

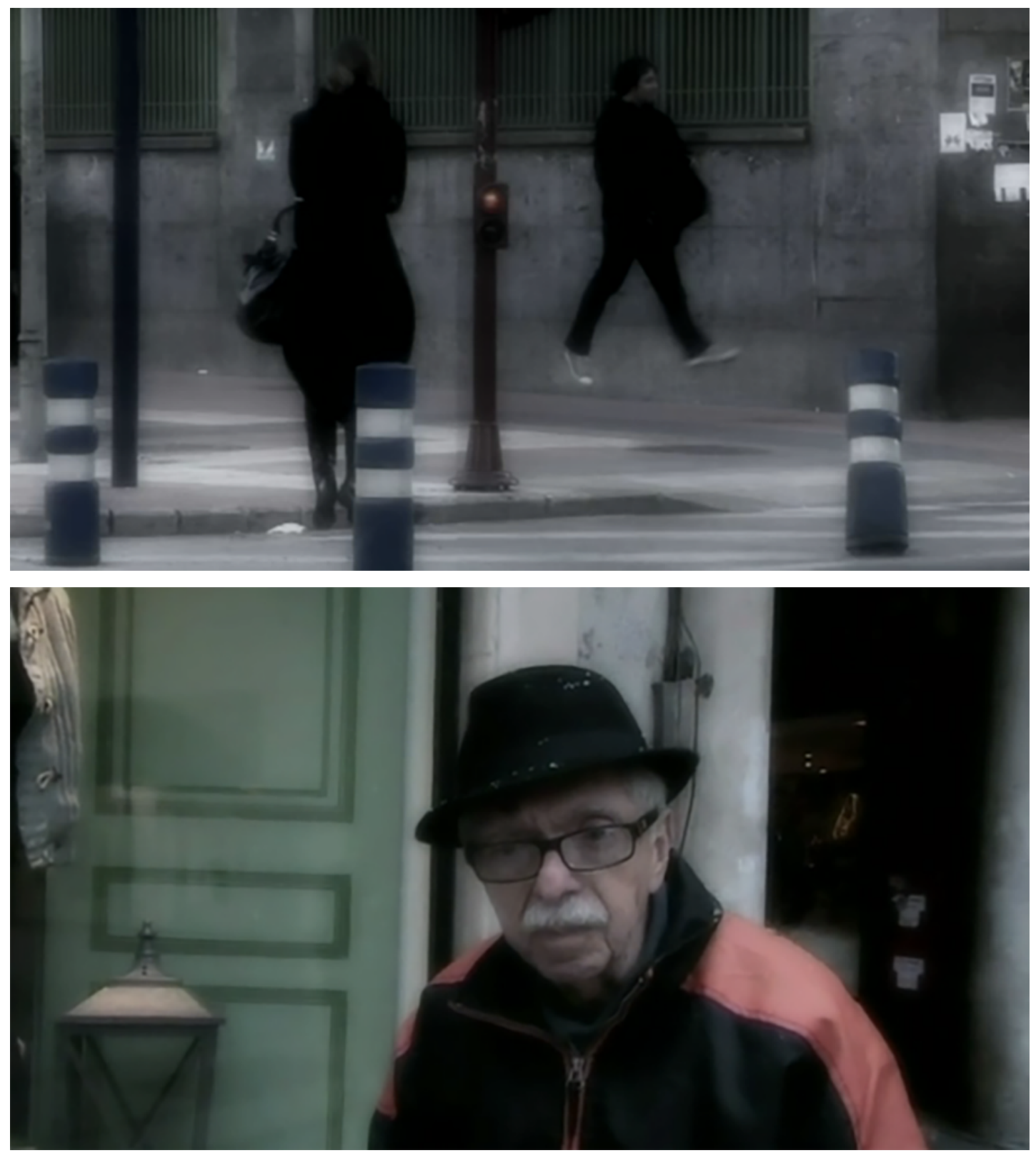

Imágenes 17 y 18: La búsqueda y reflexión sobre la imagen-emoción posibilita la superación del duelo. Duque, Ensayo final para utopía, 2012. España: Andrés Duque.

De este modo, Duque logra una intensificación emocional en oposición a la desintensificación de la subjetividad generada en Color perro que huye. En esta última, el uso de los subtítulos, fragmentarios y tangenciales, y de unas imágenes de mayor heterogeneidad, que no se centraban en el espacio íntimo, creaban una reflexión de carácter mayoritariamente social. Ensayo final para utopía logra, por el contrario, la intensificación emocional a través de un doble procedimiento: despojamiento de la imagen mediante la ausencia de texto y de sonido; manipulación de la misma en busca de la expresión emocional. 
En Las variaciones Guernica (2012), de Guillermo G. Peydró, el texto desaparece en favor de la yuxtaposición, en diferentes niveles, y como consecuencia también de la sustracción. En el prólogo de la obra escuchamos la descripción que del acontecimiento histórico del bombardeo de Guernica hace el historiador de arte T. J. Clark, sobre una imagen en negro que evidencia la omisión de cualquier imagen real del acontecimiento. Frente a este vacío, se yuxtapone a continuación un montaje de imágenes parciales del cuadro de Picasso, yuxtapuestas a su vez a una composición musical que acompañará distintos fragmentos del film (Night divison de Samuel Andreyev). La última imagen de este prólogo nos ofrece el cuadro completo en su emplazamiento museístico vacío.

Tras el título, la obra se divide en once fragmentos numerados sobre la pantalla en negro, que proponen dos tipos de yuxtaposiciones:

- Imágenes visuales de los visitantes del museo contemplando el cuadro, filmadas por el autor, yuxtapuestas a diferentes imágenes sonoras en torno a las diferentes revueltas civiles surgidas a partir de la primavera árabe (Fragmentos 1, 3, 5, 6, 7, 9 y 10$)$.

- Imágenes visuales de archivo en relación a esos mismos conflictos yuxtapuestas ahora a la composición musical ya referida (Fragmentos 2, 4 y 8).

El primer tipo de yuxtaposición 'pone en conflicto el icono de Picasso con imágenes de nuestro presente' (Peydró 2015: 265-66), sustrayendo los comentarios de los visitantes y las imágenes de los relatos, mayoritariamente periodísticos, sobre diferentes acontecimientos acaecidos en el 2011 (Imagen 19). La segunda forma de yuxtaposición presenta una imagen visual manipulada en su presentación: la imagen se reduce para convertirse en obra expuesta sobre la pantalla negra, como el cuadro sobre la pared blanca. Al igual que los visitantes de la primera yuxtaposición observan el Guernica, los espectadores del film observamos las imágenes de archivo convertidas en piezas museísticas (Gadafi leyendo el código penal libio amenazando de muerte a los manifestantes, la represión de los manifestantes en la plaza Tahrir y el desalojo del movimiento $15 \mathrm{M}$ de la Plaza de Cataluña). Este simple re-encuadre de la imagen, acompañada de la sustracción de su sonido original en favor del motivo musical, genera una frase-imagen simbolista en torno a la fusión-confusión entre la experiencia estética y la histórica (Imagen 20). 

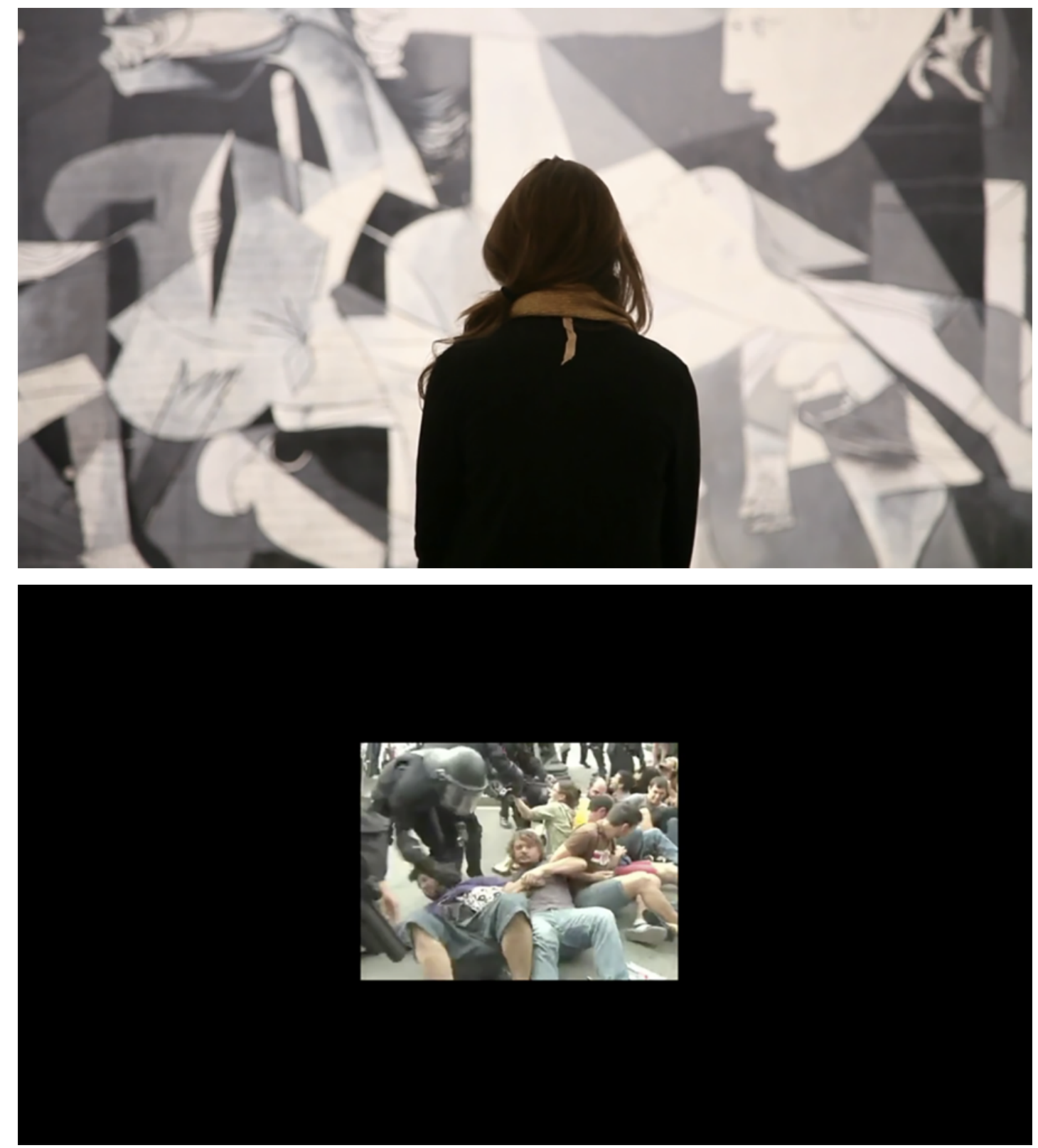

Imágenes 19 y 20: El visitante contempla el cuadro al igual que el espectador contempla las imágenes del film convertidas en cuadros expuestos. Peydró, Las variaciones Guernica, 2012. España: Guillermo G. Peydró.

De este modo, y mediante estas dos yuxtaposiciones-sustracciones, la reflexión audiovisual abandona la expresión subjetiva para desplazarse hacia el método científico. El dispositivo de enunciación se asemeja al del experimento, en el que, para resolver una incógnita - el valor de la experiencia estética para la reflexión política y social - se realizan diferentes test con el fin de alcanzar una respuesta. Ambas yuxtaposicionessustracciones se confrontan finalmente a su contrario: el documento audiovisual completo, con imagen y sonido sincrónico. Se trata del ataque aéreo norteamericano sobre civiles ocurrido en Irak en 2010 y filtrado por Wikileaks. Gracias a las 
yuxtaposiciones-sustracciones anteriores, el documento completo recupera ahora su valor histórico, ofreciendo así una actualización del bombardeo de Guernica omitido en el prólogo y simbolizado en la pintura. El significante recupera su significado. La reivindicación histórica necesita de una constante reflexión para no vaciarse de sentido.

Cuando la autoría de la imagen también desaparece en favor del found footage, tanto visual como sonoro, la subjetividad ensayística tiene como única materialización la selección y manipulación del mismo. A lo largo de su obra, María Cañas se apropia de materiales ajenos para crear un collage basado en la yuxtaposición, tanto entre imágenes visuales, como entre imagen visual e imagen sonora. Sé villana. La Sevilla del diablo (2013) es un claro ejemplo de cómo estas yuxtaposiciones generan la confrontación y descontextualización del found footage y logran 'la eliminación de toda jerarquía estética e ideología y la subsiguiente creación de un sistema estético diferente' (Oroz 2014: 69) que reflexiona sobre la 'oposición entre el discurso oficial y las prácticas populares' (2014: 73).

Como indica la autora: 'Apuesto por el apropiacionismo y el remontaje de imágenes ajenas para elaborar nuevos sentidos distintos a los de su uso primigenio' (Cañas 2014: 89). De este modo, todas las señas identitarias del discurso oficial sobre la ciudad de Sevilla son destruidas mediante una confrontación que trabaja la 'risastencia': la resistencia mediante el humor 'políticamente incorrecto, gamberro, excéntrico, fuera de protocolos y que en muchas ocasiones se transforma en una afrenta despiadada a los rituales sociales' (Cañas 2014: 89) (Imagen 21). Esta apropiación y manipulación instrumentaliza por tanto las emociones, 'las cuales son visualizadas a través de los materiales de archivo', ofreciendo una 'exploración de la memoria emocional tanto pública como privada, es decir, un tipo de memoria que aglutina ambos valores y extrae de esa combinación unas novedosas visualidades' (Català 2009: 314-15).

La imagen institucional de La Feria de Sevilla, la Semana Santa, la tauromaquia o el flamenco es confrontada con la experiencia cotidiana y real de estas expresiones culturales, convirtiendo el resultado en expresión de la protesta social (Imagen 22). La obra se materializa como reflexión sobre los procedimientos audiovisuales de creación del discurso oficial y sobre cómo combatirlo mediante la misma práctica audiovisual. Un trabajo en torno al pensamiento crítico del que participa tanto el ensayista como el espectador: 'This pulls the spectators into the film because it requires them to invest their meaning based on their relationship with the signifying elements or narratives' (Alter 2018: 7). 

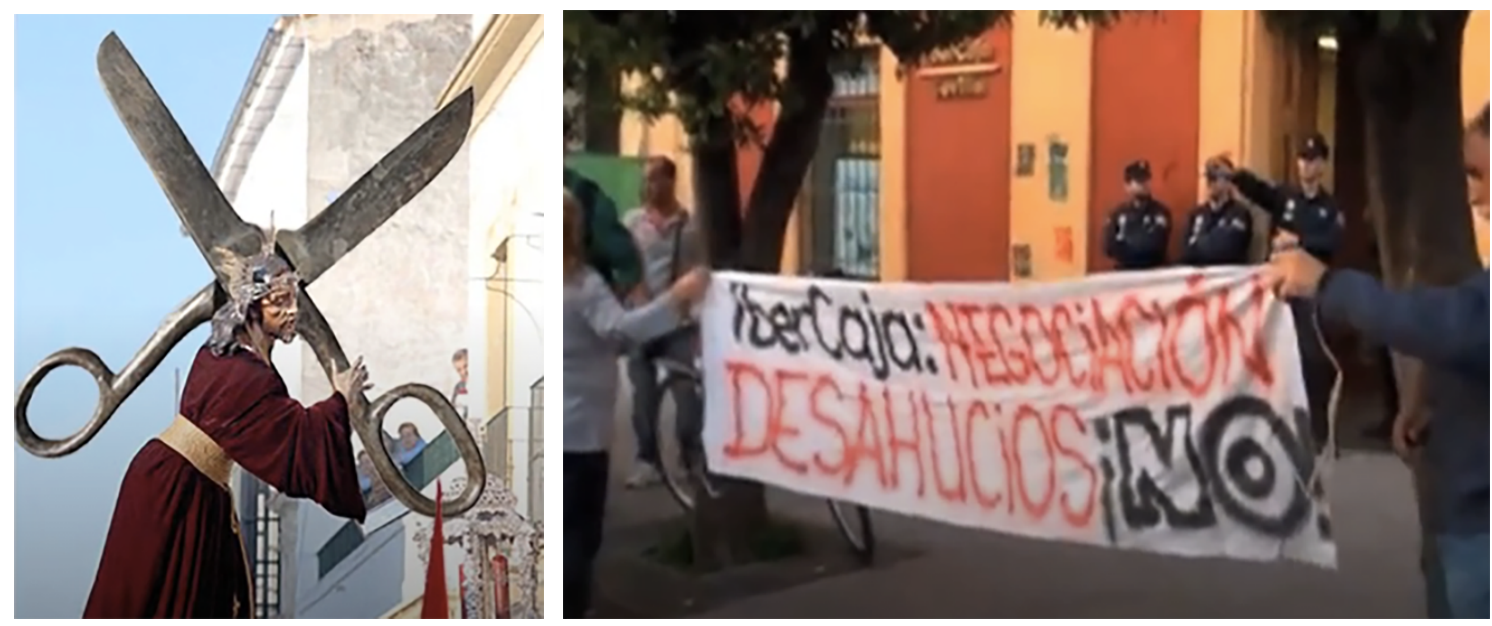

Imágenes 21 y 22: El borrado de la subjetividad directa (ausencia de texto e imágenes propias) se convierte en reflexión crítica del discurso oficial y en espacio para combatirlo. Cañas, Sé villana. La Sevilla del diablo, 2013. España: UNIA arteypensamiento.

\section{Conclusiones}

Este recorrido por el film-ensayo español contemporáneo corrobora nuestra hipótesis sobre una progresiva deconstrucción de la subjetividad ensayística y un debilitamiento de la codificación de sus dispositivos de enunciación - del uso de las formas intermediales - en favor de la multiplicación de elementos retóricos que ha posibilitado la tecnología digital. Mostramos un esquema de la evolución de los dispositivos textuales de enunciación en relación a la subjetividad ensayística.

- Ausencia del autorretrato y de la voz in

- Presencia de la voz off:

- codificación en formas intermediales (carta, diario, soliloquio)

- reafirmación de la subjetividad.

- Subtítulos:

- ficcionalización y desautomatización a través del diálogo

- desintensificación a través de las anotaciones y los microrrelatos

- Intertítulos:

- objetivación y neutralidad a través del texto informativo y reflexivo

- ficcionalización y sustracción a través del diálogo

- Desaparición del texto:

- intensificación emocional: despojamiento y manipulación 
- borrado de la subjetividad: experimento científico y activismo social / pensamiento crítico

En primer lugar, se constata una clara ausencia del autorretrato como forma intermedial de enunciación y más aún de la voz in como dispositivo textual. Se evidencia así una clara ausencia de la exploración del espacio íntimo asociado al filmensayo digital del s. XXI. Sin embargo, y siguiendo las prácticas de la modernidad, sí se instrumentalizan otras formas intermediales casi siempre asociadas a una voz off que tiende a codificar el dispositivo (la carta, el diario, el soliloquio) y se reafirma la subjetividad ensayística. Esta sufre una progresiva deconstrucción cuando la voz off se sustituye por subtítulos e intertítulos que exponen el diálogo y otras formas más fragmentarias de enunciación: anotaciones, microrrelatos, etc. Mediante los subtítulos se producen dos procedimientos diferentes. Por un lado, a través de su instrumentalización en forma de diálogo, se genera una ficcionalización de las subjetividades al tiempo que se desautomatiza la descodificación de la obra (Los materiales). Por otro, se produce una desintensificación de la subjetividad a través de la fragmentación y síntesis de las anotaciones y los microrrelatos (Color perro que huye). Los intertítulos, por su parte, ficcionalizan las subjetividades también a través del diálogo, pero, en este caso, la ausencia de imagen hace que este procedimiento vaya asociado a la sustracción (Invisible). En segundo lugar, se produce una objetivación de la subjetividad cuando el texto ofrece la neutra información o la reflexión racional ( $L a$ casa Emak Bakia, Dos cartas a Ana). Finalmente, la desaparición del texto orienta el film-ensayo en dos direcciones distintas, casi opuestas. Por una parte, esta ausencia se instrumentaliza a favor de una intensificación emocional de la subjetividad focalizada en la reflexión acerca de la imagen-emoción (Ensayo final para utopía). La ausencia de texto favorece una esencialidad de la imagen donde la emoción halla dos vías de materialización: el despojamiento y la manipulación. Por otra, la desaparición del texto supone un borrado de la subjetividad en favor de la materialización del experimento científico y/o el activismo social mediante la yuxtaposición de sonidos e imágenes (Las variaciones Guernica, Sé villana). El film-ensayo se vincula entonces de forma más evidente al desarrollo del pensamiento crítico.

En lo que respecta a los materiales visuales utilizados, la presencia exclusiva de imágenes propias y su hibridación con el found footage predomina sobre las obras que trabajan de forma exclusiva con este último. Esta fructífera hibridación se produce de 
forma mayoritaria entre imágenes en movimiento. La presencia de otros materiales audiovisuales es escasa, y se reduce casi en exclusiva a la materia fotográfica, evidenciándose la ausencia del material de animación o de la infografía. Además, la noción de collage se materializa como creación intertextual, ya sea a través del uso exclusivo de material ajeno (Las variaciones Marker) o de la hibridación con imágenes propias (La casa Emak Bakia). Por último, los elementos retóricos utilizados son muy numerosos, y del análisis realizado podemos concluir una cierta tendencia. La yuxtaposición de imágenes y sonidos (y también de subtítulos e intertítulos) gravita sobre el polo de la reflexión racional mientras que la manipulación de la imagen se vincula a la reflexión emocional.

Tras todo lo expuesto, podemos concluir cómo la subjetividad ensayística del filmensayo español contemporáneo y su pensamiento en acto han experimentado una gran expansión en este comienzo del siglo XXI, instrumentalizando los procedimientos audiovisuales desarrollados en la modernidad y creando otros nuevos. La subjetividad ensayística ha evolucionado así desde los dispositivos de enunciación que reafirmaban su presencia a una progresiva deconstrucción que amplía enormemente las posibilidades epistemológicas y estéticas del film-ensayo.

\section{References}

Alegria, O. (2012), La casa Emak Bakia, España: Emak Bakia Films.

Alter, N. M. (2018), The Essay Film after Fact and Fiction, New York: Columbia University Press.

Balló, J. (2012), 'L'estratègia del desplaçament', Comunicació. Revista de Recerca $i$ d'Anàlisi, 29:1, pp. 9-23, https://www.raco.cat/index.php/Comunicacio/article/view/264284/351937 Acceso 22 de julio 2019.

Berthet, F. (2011), 'Rêver 1'histoire: L'enfant de La Morte rouge (Solliloquio)', in C. Blümlinger, M. Lagny, S. Lindeperg, F. Niney y S. Rollet (dirs), Théâtres de la mémoire: Mouvement des images, París: Presses Sorbonne Nouvelle, pp. 83-89.

Cañas, M. (2013), Sé villana. La Sevilla del diablo. España: UNIA arteypensamiento. (2014), 'Cine Porcino, Videomaquia y Risastencia', in V. Fernández (ed.), Territorios y fronteras. Emergencias y urgencias en el cine documental español, Bilbao: Universidad del País Vasco, pp. 79-94. 
Catalá, J. M. (2005), 'Film-ensayo y vanguardia', in C. Torreiro y J. Cerdán (eds), Documental y vanguardia, Madrid: Cátedra, pp. 109-58.

(2009), 'El documental melodramático de María Cañas: ética y estética del collage', in S. García López y L. Gómez Vaquero (eds), Piedra, papel y tijera. El collage en el cine documental, Madrid: Ocho y Medio, pp. 301-30.

___ (2012), 'Guía de perplejos. El cine imposible de León Siminiani’, in V. Fernández y M. Gabantxo (eds), Territorios y fronteras. Experiencias documentales contemporáneas, Bilbao: Universidad del País Vasco, pp. 71-86.

(2014), Estética del ensayo. La forma ensayo, de Montagne a Godard, Valencia: Universitat de Valencia.

Chevalier, J. (1963), 'La caméra et le porte-plume selon Chris Marker', La revue de cinéma, 161-162, pp. 3-13.

Chion. M. (1982), La voix au cinéma. Paris: Cahiers du Cinéma / Éditions de l'Étoile.

Deleuze, G. (1985), L’'image temps, Paris: Éditions de Minuit

Duque, A. (2011), Color perro que huye, España: Hamaca Media \& Video Art. (2012), Ensayo final para utopía, España: Andrés Duque.

Echart, P. (2013), 'La casa Emak Bakia. Del cinepoema al documental de creación', Ikusgaiak. Cuadernos de Cinematografia, 8, pp. 35-54, http://dadun.unav.edu/handle/10171/53066 Acceso 22 de julio 2019.

Erice,V. (2006), La Morte Rouge (soliloquio), España: Nautilus Films.

__ (2009), Folleto de presentación del DVD de La Morte Rouge, Madrid: FNAC.

Fernández Labayen, M. y Oroz, E. (2013), 'Plug-ins del yo. Inscripciones autobiográficas en los documentales transnacionales de Andrés Duque', in M. Francés, J. Gavaldà, G. Llorca y À. Peris (coords), El documental en el entorno digital, Barcelona: Editorial UOC, pp. 101-17, https://earchivo.uc3m.es/handle/10016/22726 Acceso 22 de julio 2019.

_ (2015), 'Cosas que hacen "crack". Emociones y cinefilia en Color perro que huye (Andrés Duque, 2011)', in V. Fernández (ed.), Revisitando el cine documental: De Flaherty al webdoc, Tenerife: Sociedad Latina de Comunicación social, pp. 181204, https://e-archivo.uc3m.es/handle/10016/22715 Acceso 7 de noviembre 2018.

Fiant, A. (2014), Pour un cinéma contemporain soustractif, Saint Denis: Presses Universitaires de Vincennes.

García López, S. y Gómez Vaquero, L. (eds) (2009), 'Presentación', in Piedra, papel y tijera. El collage en el cine documental, Madrid: Ocho y Medio, pp. 9-35. 
González, B. (2006), 'El cine como forma que piensa: La Morte Rouge de Víctor Erice', Oppidum, 2, pp. 187-214, http://oppidum.es/oppidum-02-pdf/op02.08_gonzalez.pdf Acceso 22 de julio 2019.

Guerin, J. L. (2011), Dos cartas a Ana, España: Museo de Arte Contemporáneo Esteban Vicente.

Iriarte, V. (2012), Invisible, España: KREA Expresión Contemporánea Vital Kutxa, Cajaconcosasdentro.

Lacuesta, I. (2007), Las variaciones Marker, España: Prodimag.

León Siminiani, E. (2012), ‘¿Hacia una poética de la contradicción?’, in V. Fernández y M. Gabantxo (eds), Territorios y fronteras. Experiencias documentales contemporáneas, Bilbao: Universidad del País Vasco, pp. 89-99.

__ (2012), Mapa, España: Avalon, Pantalla Partida Producciones.

Los Hijos (2009), Los materiales, España: Colectivo Los Hijos.

(2012), 'Tres por dos', in V. Fernández y M. Gabantxo (eds), Territorios y fronteras. Experiencias documentales contemporáneas, Bilbao: Universidad del País Vasco, pp. 117-22.

Ménil, A. (2004), 'Quelques rémarques à propos de la notion d'essai', in S. LiandratGuigues y M. Gagnebin (dirs), L'essai et le cinéma, Paris: Éditions Champ Vallon, pp. $87-126$.

Molina Foix, V. (1984), 'Entretien avec Victor Erice', Positif, 278, pp. 47-51.

Monterrubio, L. (2018), De un cine epistolar. La presencia de la misiva en el cine moderno y contemporáneo, Santander: Shangrila Ediciones.

(2019), 'La Morte Rouge (soliloquio) de Víctor Erice: Del trauma a la fraternidad: el intersticio entre realidad y ficción', in N. Mínguez (ed.), Itinerarios y formas del ensayo audiovisual, Barcelona: Gedisa, pp. 113-34.

Moure, J. (2004), 'Essai de définition de l'essai au cinéma', in S. Liandrat-Guigues y M. Gagnebin (dirs), L'essai et le cinéma, Paris: Éditions Champ Vallon, pp. 25-39.

Oroz, E. (2014), ‘i(Se)villana, tuvo que ser!’, in V. Fernández y M. Gabantxo (eds), Territorios y fronteras. Experiencias documentales contemporáneas, Bilbao: Universidad del País Vasco, pp. 67-77.

Ortiz, I. (2014), 'La canción de amor (y desamor) de Víctor Iriarte', Kulturaladia, 18 de febrero, http://www.kulturaldia.com/peliculas/la-cancion-de-amor-y-desamor-devictor-iriarte/ Acceso 22 de julio 2019. 
Pedro, G. de (2012), 'Hijos sin hijos. Un disparo en medio de un concierto', in V. Fernández, y M. Gabantxo (eds), Territorios y fronteras. Experiencias documentales contemporáneas, Bilbao: Universidad del País Vasco, pp. 109-14.

Peydró, G. G. (2012), Las variaciones Guernic, España: Guillermo G. Peydró (2015), 'Las variaciones Guernica. Film-ensayo sobre arte', in M. Álvarez, H. Hatzmann e I. Sánchez Alarcón (eds), No se está quieto: Nuevas formas documentales en el documental hispánico, Madrid: Iberoamericana, pp. 265-75.

Rancière, J. (2011), El destino de las imágenes, Nigrán: Politopías.

Rascaroli, L. (2017), How the Essay Film Thinks, Oxford: Oxford University Press.

Renov, M. (2004), The Subject of Documentary, Minneapolos: University of Minnesota Press.

Ricaurte, P. (2014), 'Hacia una semiótica de la memoria', En-claves del pensamiento, $8: 16$, pp. 31-54,

http://www.scielo.org.mx/scielo.php?script=sci_arttext\&pid=S1870879X201400020003

1. Acceso 22 de julio 2019.

Vilches, O. (2014), 'La melodía del afilador: Apuntes sobre Invisible, de Víctor Iriarte', in V. Fernández (ed.), Territorios y fronteras. Emergencias y urgencias en el cine documental español, Bilbao: Universidad del País Vasco, pp. 35-45.

Weinrichter, A. (ed.) (2007), 'Un concepto fugitivo: Notas sobre el film-ensayo', in $L a$ forma que piensa. Tentativas en torno al cine-ensayo, Pamplona: Festival Internacional de Cine Documental de Navarra, pp. 18-48.

Zunzunegui, S. (2014), 'Escribir el cine: La pasión cinefílica en la obra de Víctor Erice', L'Atalante. Revista de estudios cinematográficos, 18, pp. 52-59, http://www.revistaatalante.com/index.php?journal=atalante\&page=article\&op=view \&path $\% 5 \mathrm{~B} \% 5 \mathrm{D}=243 \&$ path $\% 5 \mathrm{~B} \% 5 \mathrm{D}=191$ Acceso 22 de julio 2019.

\section{Contributor details}

Lourdes Monterrubio es doctora por la Universidad Complutense de Madrid (UCM), dentro del programa Literatura y Artes plásticas: Estudio comparado de los distintos lenguajes artísticos. Anteriormente cursó la diplomatura en Dirección Cinematográfica en la ECAM de Madrid. Miembro del grupo internacional de investigación UCM La Europa de la escritura, es especialista en las relaciones entre literatura y cine y en las escrituras fílmicas del yo. Ha publicado el monográfico De un cine epistolar: La 
presencia de la misiva en el cine francés moderno y contemporáneo (2018) y numerosos artículos sobre cine moderno y contemporáneo.

Contact:

Departamento de Estudios Románicos, Franceses, Italianos y Traducción.

Complutense University of Madrid.

E-mail: loumonte@ucm.es

https://orcid.org/0000-0003-0566-3666 